\title{
The Availability and Assessment of Potential Agricultural Residues for the Regional Development of Second-Generation Bioethanol in Thailand
}

\author{
Piradee Jusakulvijit ${ }^{1,2}$ (D) A Alberto Bezama ${ }^{1}$ (D) . Daniela Thrän ${ }^{1,2,3}$ (D)
}

Received: 27 July 2020 / Accepted: 12 March 2021 / Published online: 29 March 2021

(c) The Author(s) 2021

\begin{abstract}
The agricultural sector is a major source of biomass feedstocks for biofuels. Even though biomass potential in Thailand has been analyzed on a national level, its distribution and potential have yet to be assessed on a regional and provincial scale. Therefore, the study aims to verify the possibility of decentralized second-generation bioethanol production from regionally available agricultural residues. Most of the generated residues stem from the country's major crops (sugarcane, cassava, rice and palm), totaling 174.1 million tons per year. The volume of bioethanol from these residues is projected to be 20,213.5 million liters per year, meeting $31.2 \%$ of the overall fuel demand of the transport sector. At the regional level, the northeast produces the highest amount of bioethanol at 9099.7 million liters per year, followed by the central, northern and southern regions. In terms of provincial distribution, the highest amount of bioethanol is converted in Nakhon Ratchasima, amounting to 1328 million liters per year. Data from the top ten potential provinces suggest that decentralizing production facilities is possible. One of the hotspots is Surat Thani in the south which can potentially utilize palm residues as feedstocks. This regionalized assessment also found that conventional feedstocks could be substituted with regionally available residues in the 26 production plants currently in operation. The results confirm that there would be enough alternative regional feedstocks to meet existing production capacities and they indicate that there would be enough regional residues left over for future value-added utilization.
\end{abstract}

Piradee Jusakulvijit

piradee.jusakulvijit@ufz.de

1 Department of Bioenergy, Helmholtz Centre for Environmental Research - UFZ, Permoserstr. 15, 04318 Leipzig, Germany

2 Faculty of Economics and Management Science, University of Leipzig, Germany, Augustusplatz 10, 04109 Leipzig, Germany

3 Deutsches Biomasseforschungszentrum gGmbH - DBFZ, Torgauerstr. 116, 04347 Leipzig, Germany 


\section{Graphic Abstract}

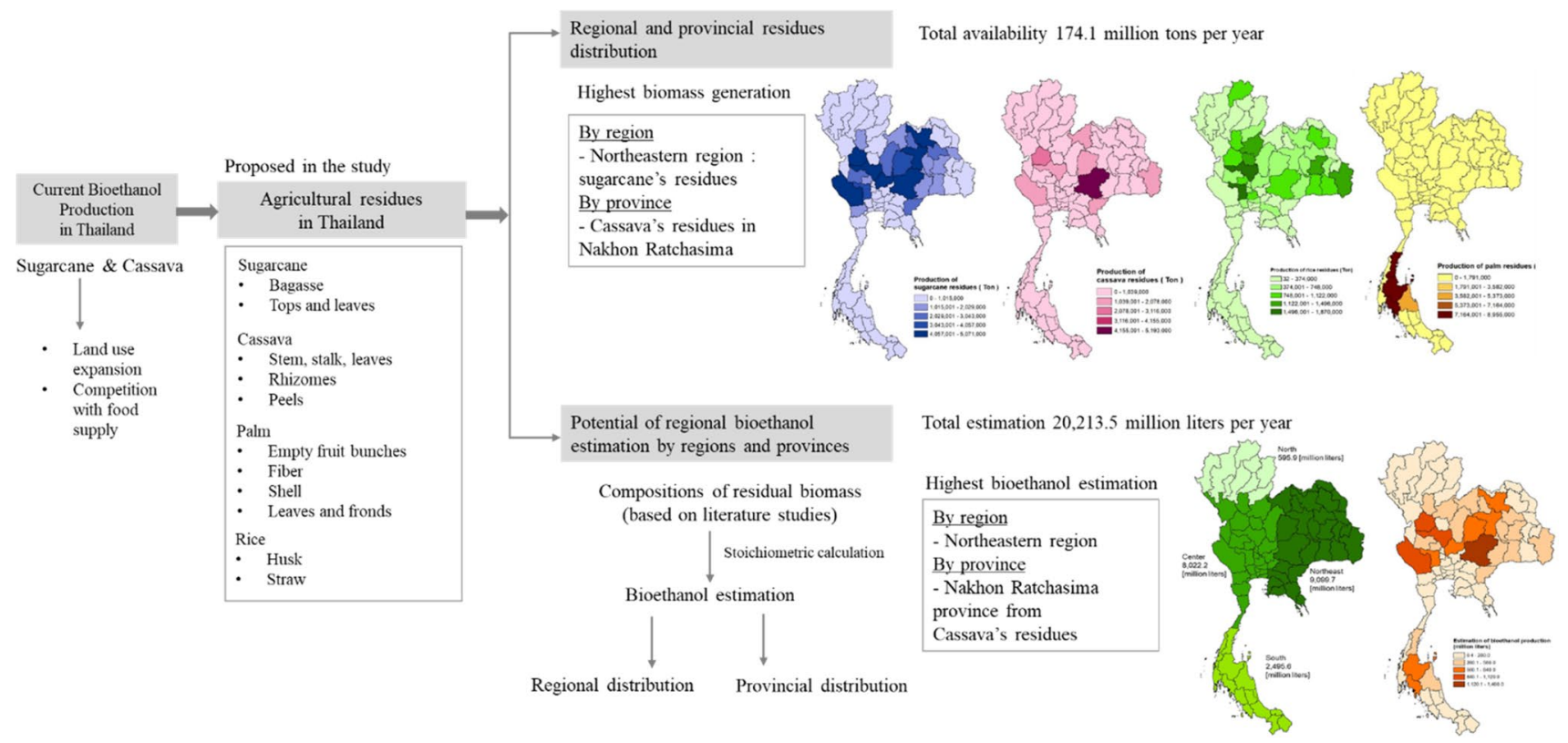

Keywords Bioethanol in Thailand - Agricultural residues · Lignocellulosic biomass · Second-generation bioethanol · Regional bioethanol potentials $\cdot$ Regionalized assessment

\section{Statement of Novelty}

The novelty of the present study is the regionalized assessment of agricultural residues from the production of major crops in Thailand and the preliminary estimation of the potential second-generation bioethanol production. This is the first time that such a regionalized approach has been utilized and the findings should help determine the actual potential bioethanol production capacities and the regional infrastructures that would be able to achieve optimized biomass utilization. By using a stoichiometric calculation, it is possible to project the maximum volume of bioethanol. The results have shown that the residues from sugarcane, cassava, rice and palm can be converted into a promising volume of bioethanol. In addition to the hotspots in the northeastern and central regions, the results suggest that the possibility of using palm residues in the southern region could make it the first potential area for decentralized production. The study could help support decisions surrounding compliance with Thailand's strategic bioethanol development plan.

\section{Introduction}

As a result of its population growth, thriving economy and urbanization, Thailand has been a net importer of energy for decades. The country has had to import fossil fuels to cover domestic consumption, which account for around
$60 \%$ of its total primary energy [1]. A recent report showed that the import of crude oil increased by $17 \%$ between 2008 and 2018 [2]. Regardless of the fact that the global price of crude oil peaked at over 150 USD per barrel during the world energy crisis, there has been a steady increase in the demand for fossil fuels. According to a recent report, there has been a constant rise in demand for energy in the transport sector, increasing from 7121 million liters to 11,373 million liters over the last decade (figures from 2008 and 2018 , respectively). This has led to the current shares in the energy sector, where the transport sector makes up $40 \%$ of the final energy consumption [2]. The increased demand for gasoline is confirmed by the fact that the number of gasoline-powered cars has increased by $39.9 \%$ in 10 years [3].

A projected progressive economic growth rate in the future has led to an increased awareness by the Thai government of the need to reduce fossil fuels, resulting in the launch of several renewable energy policies [4]. A stable commodity supply is a key driver behind the government's desire to ensure domestic energy sources which can mitigate the country's dependency on imported energy from overseas. In addition, the goal to reduce $25 \%$ of the greenhouse gas (GHG) emissions from "business as usual" by 2030 has led to the need to look for new sources to replace fossil fuels [5].

One of the solutions for meeting energy demands and reducing the country's dependency on imported fossil fuel 
has been to utilize domestic agricultural crops in energy production. Due to its suitable climate and favorable landscapes, Thailand has become a net exporter in agricultural products, which make up 16\% of total exports [6]. The agricultural business has played a crucial role in supporting citizens in sectors such as food supply, agro-industries and employment. Similarly, for the energy sector, the government has fostered the agricultural-based economy by incorporating sugar and starch-based biomass into bioethanol production, and helped sugarcane and cassava become key players by increasing their share in biofuel production as substitutes for imported crude oil. As a result, the country set a sizable goal in the form of a 20-year development plan, namely the Alternative Energy Development Plan (AEDP). It also mandated mixing a percentage of bioethanol with gasoline, aiming for this to make up 20-25\% of final fuel consumption by 2036 , up from $15.2 \%$ in 2018 [7].

Although there are many reasons for the success of the biofuel market, most notably due to a decades-long push by the government for such policies [8], conventional biofuel development has received more attention due to the controversy surrounding potential negative environmental effects found by many studies [9-11]. Conventional methods for producing sugarcane can bring up several environmental issues, such as the use of fertilizers and pesticides to increase crop yield per area, and open field burning to prepare the land, which releases GHG and some fine particles such as PM 2.5, causing haze in the atmosphere [11, 12]. Moreover, the promotion of bioethanol production could likely prompt an expansion of cropland, which would result in the displacement of land for food crops. As a result, crop cultivation could affect change in soil carbon and necessitate carbon debt due to direct land use change (dLUC) [13-15]. In addition to the possiblity of expanding land use, food security is considered one of the other issues limiting the development of the bioenergy sector [16].

In recent years, the utilization of agricultural residues has become a promising, sustainable way of replacing conventional feedstocks [17]. Residual biomass from crop cultivation is an important biomass resource that can play several roles in the biorefinery industry [18]. The role of agricultural residues has been successfully verified in terms of its environmental benefits in bioethanol production and biomass power generation $[8,19,20]$. Thailand has a variety of residual biomass streams in the agricultural sector, distributed over many locations. Nonetheless, the leftover biomass from these crops is generally utilized as feed for livestock or as construction material. Some types of biomass residues are currently being used on an industrialized level in power generation, based on the concept of thermochemical conversion, for instance, through the process of direct combustion or gasification of rice husks [20,21].
Potential residual biomass from post-harvest and agricultural production processes has been a target of revalorization through ethanol conversion due to its substantial generation rates and the fundamental structure of its saccharide components. Several studies have verified the data on bioethanol conversion from agricultural residues, for example from bagasse, rice husks, cassava peels and oil palm residues [20, 22-24]. Despite the properties of lignocellulosic biomass, lignocellulosic ethanol still faces certain constraints when it comes to developing it on an industrial scale [21, 25, 26]. In addition to improvements in technical feasibility, the conversion of agricultural residues to bioethanol requires an evaluation of residue selection, improvements to the agroindustry, and a sustainability assessment [27, 28]. Since an analysis of the potential utilization of residual biomass from crop cultivation generally also encompasses the process of material transportation [27, 29], logistics management is also a factor considered in the techno-economic feasibility, as transport distance has been found to make up a large portion of the logistics costs [30-32].

At present, bioethanol production plants in Thailand are considered to be a centralized production system, predominantly located in the areas where conventional crops are concentrated. However, clusters of large-scale infrastructures inevitably face such disadvantages as transportation, management of immense amounts of material, and the inflexibility of feedstocks due to seasonal dependence [33]. In contrast, the development of small-scale plants has been received more favorably due to their ability to utilize a wider variety of resources, increasing flexible feedstock options for each harvesting season [34]. Moreover, the decentralized system has been investigated with regard to the possibility of handling multiple types of biomass feedstocks that are blended in biorefineries [35].

In this regard, rather than a one-dimensional promotion of biofuel as is currently being practiced, the decentralization of the agro-industries is a promising way to enhance accessibility to biomass resources and encourage the mobility of dispersed resources in Thailand. The system utilizes local residual biomass and contributes to the profitability and sustainability of local residents [36]. Studies have shown that a decentralized approach with a model of introducing various feedstocks reduces the impact of the seasonality of crops by allowing multiple feedstocks to be mixed [34, 37]. At the same time, the concept of using regional biomass in the bioenergy production system has shown to have socioeconomic and environmental benefits as a result of localized interaction and a secure energy supply [38-40]. The local utilization of agricultural residues is considered a feasible way of mitigating environmental effects when it comes to materials management [41] and it creates additional income opportunities in the farming community [42]. Providing 
residual resources to manufacturing facilities could benefit economic and environmental sustainability $[32,43]$.

Therefore, not only does the current study encourage the transition away from conventional feedstocks towards alternative residues, it assesses the regional potential of agricultural residues in Thailand with regard to availability, biomass properties, and the possibility for bioethanol conversion on a provincial and regional scale. Although biomass potentials from crop production in Thailand have already been investigated [17, 44], the proposed scope of this work adds value through the regionalized assessment of agricultural residues from an up-to-date list of major crops based on statistics from Thailand's agricultural sector. Furthermore, stoichiometric bioethanol estimates based on agricultural residues generated on a regional and provincial scale and which illustrate spatial distribution are a way to motivate regional residue utilization in second-generation ethanol production. The regional availability of major biomass streams and potential bioethanol allocation, as identified in this study, aims to provide a comprehensive picture of major sources of biomass for further system optimization and installation of decentralized facilities.

\section{Materials and Methods}

Although biomass distribution has been investigated with respect to power generation technology [45], to the best of the author's knowledge, no research has been conducted on residue distribution from a spatial perspective with regard to second-generation bioethanol production in Thailand. Quantifying crop residues and estimating potential bioethanol from key agricultural products on a national and provincial level constitute the novelty of this study. Hence, in order to cover its main aim, this research paper is divided into three main sections: (1) regional availability of agricultural residues (2) estimating potential bioethanol from the expected biomass (3) proposal of potential areas for secondgeneration bioethanol production.

\section{Literature Review on the Background of the Bioethanol Market in Thailand}

To obtain a primary overview, a review of the development of the bioethanol market in Thailand was conducted using reports, statistical data and published studies. Using historical data to examine bioethanol demand was expected to reveal the growing trend in the future. Thus, the review focused on consumption and production based on the trends from past events, including the important milestones of policies implemented between 1992 and 2018. With respect to bioethanol production, the data on feedstock quantities was gathered in this study for a 10-year period: 2009-2018.
In order to understand the background of ethanol production in Thailand, statistics on sugarcane and cassava crops, as current feedstocks, were gathered for the period of 2007-2018. Furthermore, the study calculated crop yields per area based on total production and cultivation areas in order to address the issue regarding the expansion of land use for cultivation.

\section{Selection of Potential Agricultural Residues}

This paper explores the potential biomass to answer the question of whether regional biomass can be utilized as an alternative feedstock in future bioethanol production. Four major potential crop residues were selected in this study in order to obtain quantitative data on residue production based on the production statistics of major crops. In addition to calculating annual quantities, the area of crop cultivation was used to calculate the density of residue generation in terms of yield per area.

In an initial step, the most-produced residual biomass was identified based on data on major agricultural production, biomass data, and the biomass yield per area as reported by the Department of Alternative Energy Development and Efficiency (DEDE) [46-48]. Using the historical data, it was possible to narrow down the selection to four major crop residues. However, it is necessary to estimate biomass potential from the most updated sources. To obtain up-todate figures on residues from crop production, the amount of generated residue was calculated based on the current statistical data on crop production for 2018, published by the Office of Agricultural Economics (OAE) [46]. As an exception, data on sugarcane production was collected from the Office of the Cane and Sugar Board [48].

Additionally, the backgrounds of the selected residues were described in the context of current utilization. The possible use of agricultural biomass for higher value added applications was included in the study in order to emphasize these elements of bioenergy use.

\section{Analysis of the Distribution of Agricultural Residues}

First, as part of a preliminary investigation, total residue quantities were estimated for the selected types of biomass. The data on crop production was used to calculate the residue-to-crop ratio $(R S C)$ in order to estimate the realistic amount of available residues. The availability of biomass was determined using Eq. (1), which has been applied in several studies $[24,49,50]$. The amount of biomass, $Q_{b}$, was calculated by multiplying agricultural crop production in $2018\left(Q_{c}\right)$ with the $R S C$ which was gathered and averaged from several related publications (Table 1). Next, generated residues were used to calculate production per area (tons per hectare) based on the total cultivation land for each type 
of crop. This step captures the overall picture of residue production density.

$Q_{b}=Q_{c} \cdot R S C$

In addition to residue availability based on residue type, the distribution of the generated residues was examined with regard to regional potential. We divided the studied area into four main geographical regions, i.e., north, northeast, central and south. Each type of generated residue was broken down for each region. Categorizing by region is expected to demonstrate the prospective clusters and identify the dominant agricultural residues based on the highest proportions in the respective regions.

Next, biomass distribution was calculated on a provincial scale by dividing the country into 77 administrative provinces. Each agricultural residue was examined with respect to total residue generation per province (tons) and residue yield per area (tons per hectare). Crop density, i.e. quantity per area, was calculated on a provincial scale using the land use information for crop cultivation in each province from the OAE [46].

The obtained data was then used to create map-based information using ArcMap, a software for geographic information systems (GIS). This assessment was aimed at establishing the distribution of the residues with respect to quantity and density.

\section{Estimation of Potential Ethanol by Region and Province}

In addition to the availability of agricultural residues distributed throughout the country, potential bioethanol was

Table 1 Average values of the residue-to-crop ratio for each type of agricultural residue

\begin{tabular}{llll}
\hline Crop & Type of residue & $\begin{array}{l}\text { Average values for } \\
\text { residue- to-crop ratio } \\
(\text { RSC })\end{array}$ & References \\
\hline Sugarcane & Bagasse & 0.31 & {$[51-54]$} \\
& Tops and leaves & 0.25 & {$[12,55-57]$} \\
Cassava & Pulp (starch and & 0.24 & {$[58-61]$} \\
& fiber) & & \\
& Peel & 0.28 & {$[62-64]$} \\
& Stem and leaves & 0.12 & {$[65-67]$} \\
& Rhizome & 0.35 & {$[47,68,69]$} \\
Rice & Straw & 0.80 & {$[47,49,70]$} \\
& Husk & 0.22 & {$[47,54,71]$} \\
Palm & Empty fruit bunches & 0.21 & {$[72-74]$} \\
& Fiber & 0.15 & {$[75,76]$} \\
& Shell & 0.09 & {$[75-78]$} \\
& Leaves (fronds) & 2.01 & {$[47,79]$} \\
\hline
\end{tabular}

calculated based on the properties of the biomass and the quantity of each available type. However, it is necessary to identify ethanol production potential in terms of spatial distribution because different areas contain different proportions and compositions of residues. This means that ethanol hotspots are dependent not only on the concentrated quantity of biomass but also on the bioethanol convertibility from the respective biomass. The regionalized assessment must emphasize the possibility of decentralized bioethanol plants in order to support regional biomass utilization.

Therefore, major biochemical components containing cellulose and hemicellulose were used to estimate the ethanol conversion. The composition values of the individual residual streams were gathered from the literature reviews and averaged, as presented in Table 2. Since ethanol volumes need to be estimated based on the quantity of dry biomass, the utilizable amount of residual biomass was determined using Eq. (2). After quantifying residues using Eq. (1), dry residues $\left(U_{b}\right)$ were obtained by excluding moisture content (M).

$U_{b}=Q_{b} \cdot(1-M)$

Bioethanol production from lignocellulosic biomass is associated with more complications than production from starch or sugar-based biomass. The process of bioethanol production from cellulosic feedstock requires three main steps: pretreatment, hydrolysis and fermentation. Pretreatment is essential before carrying out hydrolysis and fermentation since this process deconstructs the polysaccharides into soluble sugars to increase the accessibility of chemicals, enzymes and micro-organisms. This enables further steps to function effectively [97, 98].

Next, the hydrolysis process converts polymeric sugars into monomeric sugars to obtain fermentable substrates, producing glucan and xylan from cellulose and hemicellulose, respectively. Principally, hydrolysis is achieved through acid hydrolysis or enzymatic hydrolysis [99]. After the hydrolysis process, the substrates are ready to undergo fermentation. Bioethanol conversion happens during this process by ethanol-producing microbes, such as yeast or anaerobic, thermophilic bacteria. A variety of end products is achieved by applying different types of microbes. The yeast Saccharomyces cerevisae is commonly used as a fermentation microorganism in this process.

Even though different pretreatment methods achieve different ethanol yields, the principles of biochemical compositions and the ethanol conversion process can be used to theoretically estimate ethanol yields using stoichiometric calculations. In the present study, ethanol quantities were estimated using the calculation method described by Demirbas et al. [100]. According to the process diagram presented in Fig. 1, two major components 
Table 2 Moisture content and biochemical composition of the selected residues

\begin{tabular}{|c|c|c|c|c|c|c|c|}
\hline \multirow[t]{2}{*}{ Crop } & \multirow[t]{2}{*}{ Type of residue } & \multirow[t]{2}{*}{$\begin{array}{l}\text { Moisture content } \\
(M) \text { [\% weight }]\end{array}$} & \multicolumn{4}{|c|}{$\begin{array}{l}\text { Average value of composition from literature as } \\
\text { calculated in this study [\% dry weight] }\end{array}$} & \multirow[t]{2}{*}{ References } \\
\hline & & & Starch & Cellulose & Hemicellulose & Lignin & \\
\hline \multirow[t]{2}{*}{ Sugarcane } & Bagasse & 50.4 & - & 37.3 & 23.5 & 19.5 & {$[12,17,47,51-54,80-82]$} \\
\hline & Tops and leaves & 20.0 & - & 32.4 & 26.1 & 17.1 & {$[12,56,57,82-85]$} \\
\hline \multirow[t]{4}{*}{ Cassava } & Pulp (starch and fiber) & 78.8 & 61.1 & 25.5 & 6.4 & 2.4 & {$[59-61,86]$} \\
\hline & Peels & 70.8 & 27.5 & 7.5 & 26.2 & 4.8 & {$[63,64,87]$} \\
\hline & Stem and leaves & 52.1 & - & 35.0 & 17.8 & 21.1 & {$[65,66,68]$} \\
\hline & Rhizomes & 29.6 & - & 42.7 & 22.0 & 24.7 & {$[47,68,69]$} \\
\hline \multirow[t]{2}{*}{ Rice } & Straw & 33.9 & - & 34.8 & 27.2 & 17.9 & {$[49,65-71]$} \\
\hline & Husk & 9.6 & - & 29.1 & 20.8 & 17.5 & {$[72-75]$} \\
\hline \multirow[t]{4}{*}{ Palm } & Empty fruit bunches & 63.9 & - & 43.7 & 24.7 & 17.9 & {$[73,74,88-92]$} \\
\hline & Fiber & 7.5 & - & 30.7 & 29.5 & 26.9 & {$[24,75,93]$} \\
\hline & Shell & 7.1 & - & 23.0 & 22.2 & 48.7 & {$[24,75,77,89,93-95]$} \\
\hline & Leaves (fronds) & 72.5 & - & 35.1 & 27.1 & 24.4 & {$[88,96]$} \\
\hline
\end{tabular}

of lignocellulosic biomass-cellulose and hemicellulose-are represented as $C$ and $H$, respectively. In addition to the lignocellulosic content, the value of starch content, $S$, needs to be considered due to the residual starch in cassava by-products. Therefore, the conversion pathway from starch to glucose and ethanol production was also taken into consideration. For the first step of the pathway, the content of the polysaccharides $(C, H$, $S$ ) are hydrolyzed to monosaccharides resulting in the hydrolysis efficiencies $H_{c}, H_{h}$, and $H_{s}$ for cellulose, hemicellulose and starch, respectively. Next, bioethanol fermentation efficiencies are indicated as $F_{c}, F_{h}$ and $F_{s}$ for the ethanol conversion pathways from glucose, xylose and the starch-derived glucose, respectively. The value of each factor used in the present calculation is presented in Table 3.
The content values of $C, H$, and $S$ were analyzed based on experimental results as reported in the scientific literature. For the hydrolysis step, the values for hydrolysis efficiency from cellulose and hemicellulose, $H_{c}$, and $H_{h}$, were defined by this study as 0.76 and 0.90 respectively [101]. The saccharification of starch to glucose $\left(H_{s}\right)$ is converted using 1.111 as a theoretical conversion factor. In the next step, the monomeric saccharides glucose and xylose are fermented with the fermentation efficiency, $F_{c}$ and $F_{s}$, being 0.75 and 0.50 respectively [100]. For the starch to ethanol pathway, fermentation efficiency $\left(F_{s}\right)$ was used with a stoichiometric yield from glucose of 0.5111 [101].

Detailed calculations are described in Eqs. (3-7). The theoretical conversion factor, according to the stoichiometric yield of ethanol fermentation from glucose, is $0.5111 \mathrm{~kg}$ ethanol $\mathrm{kg}$-glucose $\mathrm{e}^{-1}$. At the same time, the theoretical

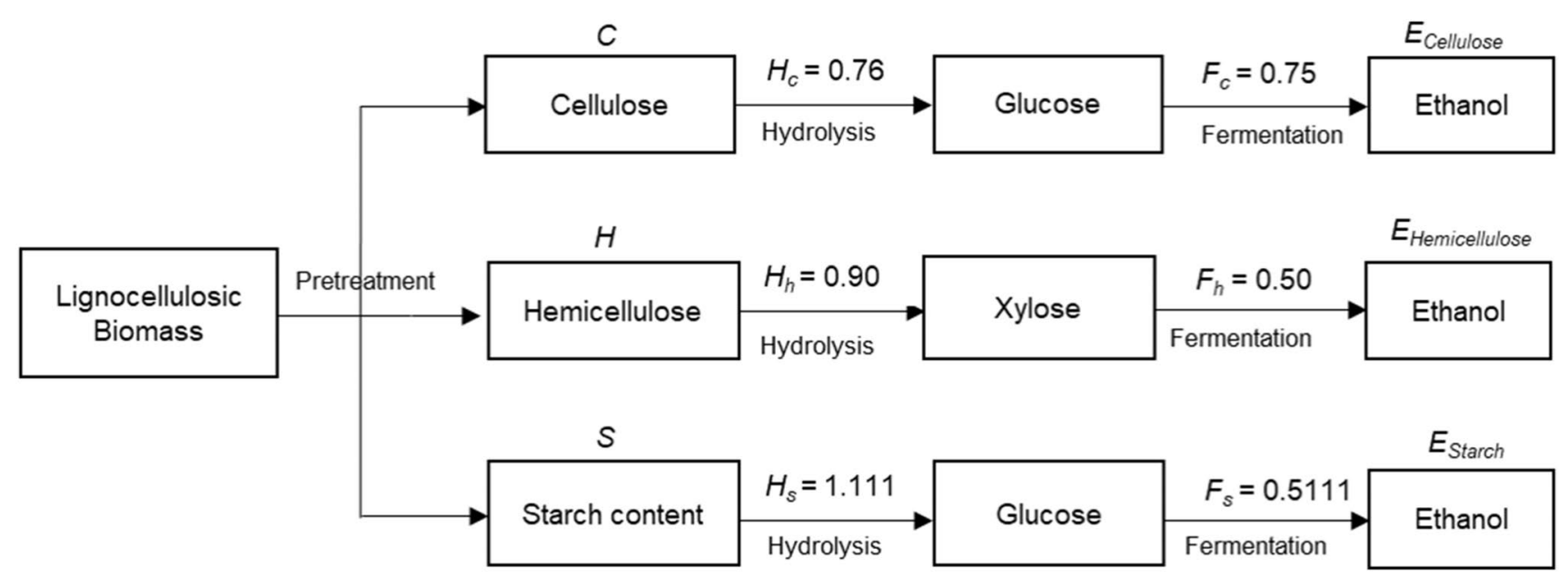

Fig. 1 Bioethanol conversion pathway from lignocellulosic biomass and the conversion factors used in the stoichiometric calculation 


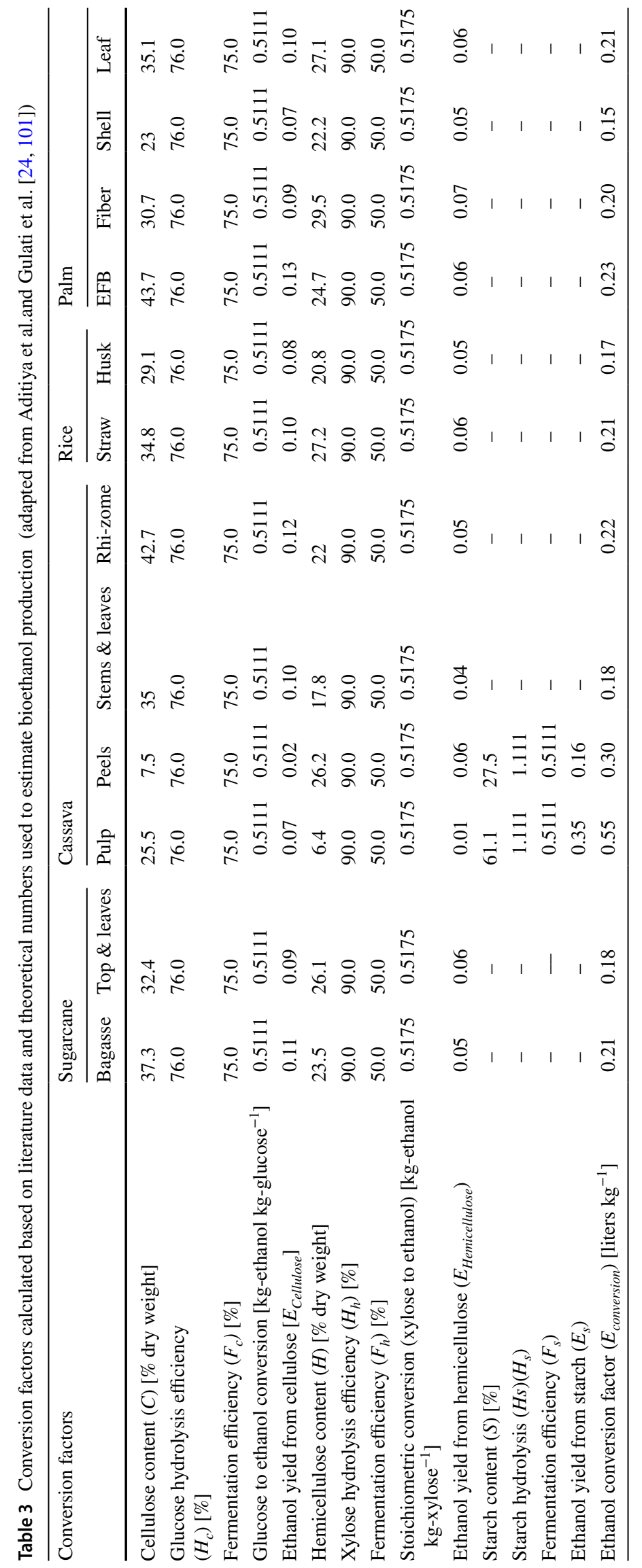


transformation of xylose to ethanol is 0.5175 [104]. After establishing all factors for the bioethanol transformation pathways, the total volume of ethanol is determined as described in Eqs. (3-7) by applying them to the dry residues and converting using an ethanol density of 0.7893 liters $\mathrm{kg}^{-1}$.

$E_{\text {Cellulose }}=0.5111 \cdot C \cdot H_{c} \cdot F_{c}$

$E_{\text {Hemicellulose }}=0.5175 \cdot H \cdot H_{h} \cdot F_{h}$

$E_{\text {Starch }}=S \cdot H_{s} \cdot F_{s}$

$E_{\text {Conversion }}=\frac{\left(E_{\text {Cellulose }}+E_{\text {Hemicellulose }}+E_{\text {Starch }}\right)}{0.7893}$

$V_{\text {Ethanol }}=U_{b} \cdot E_{\text {Conversion }}$

$E_{\text {Cellulose }}, E_{\text {Hemiellulose }}$ and $E_{\text {Starch }}$ are the respective ethanol yields from cellulose, hemicellulose and starch content. $E_{\text {Conversion }}$ represents a total bioethanol conversion factor, while $V_{\text {Ethanol }}$ is the total estimated volume of ethanol calculated from the acquired conversion factors with the confirmed amount of residues $\left(U_{b}\right)$.

To confirm the certainty of this calculation method, the study double-checked the evaluation by applying the same analysis method to the starch composition and moisture content of cassava. As reported in the literature, the moisture content of fresh cassava is 59-70\%, and the average starch content of dry cassava biomass is 77-94\% [102]. Applying this initial data to Eqs. (5) and (6) produces a starch to bioethanol conversion rate of $5.5 \mathrm{~kg}$ fresh cassava per liter of ethanol. This figure is similar to other studies that found $5.5-7.3 \mathrm{~kg}$ of fresh cassava are required to produce a liter of ethanol [103, 104].

After obtaining the ethanol conversion factors as summarized in Table 3, the factors were applied to the respective residues to estimate the potential volume of bioethanol production. Similar to the analysis of biomass distribution), the regional potential of ethanol was assessed by dividing it into 4 regions and 77 administrative provinces throughout the country. Then, the spatial data of potential bioethanol hotspots were converted to GIS data, which was assumed to be a useful tool in determining the potential areas for the regional development of industrial infrastructure. Based on the ethanol estimation for each provincial area, the top ten provinces were identified with respect to the highest expected ethanol production capacities along with the clarifications on the proportion of available feedstocks.

Another aim of this study was to propose alternative feedstocks and to evaluate potential production in existing plants by comparing this with the ethanol production capacity in installed bioethanol plants. This can be considered an initial benchmark before developing scenario verifications in the future. The study identified the location of ethanol producers operating in the different the provinces and regions. This information was collected from statistics published in 2019, which was the latest source of data available [105].

In order to evaluate the replacement of conventional materials by alternative feedstocks, the amount of collectable residues was first calculated by multiplying the highest volume of available residues identified in this study with the collection efficiency. Equation (8) was used to obtain the provincial scale of collectable biomass yield per year. The collection efficiency in this study was assumed to be $50 \%$ of the available amount in accordance with the study by Gadde et al. on energy applications in the field of electricity generation [49]. Next, the required amount of alternative feedstocks was calculated using the ethanol conversion factors in this paper, varying for each type of residual biomass. This was based on the current production capacities of the ethanol plants in the respective provinces. The calculation method is described in Eq. (9).

Lastly, in order to confirm there are enough residues to supply the production plants, the ratio of required feedstock to the amount of collectable biomass was verified as shown in Eq. (10). This calculation is based on the assumption that bioethanol is produced by locally utilizing available biomass within the same province as the operating plant. In order to determine whether there is a sufficient supply to meet the current production volumes of bioethanol, the percentage of the required amount of feedstocks has to be equal to or lower than $100 \%$ of the collectable residue yield.

Collectable residue yield $\left[\right.$ tons year $\left.^{-1}\right]=$ Residue availability $\left[\right.$ tons year $\left.^{-1}\right] \cdot$ Collection efficiency [\%]

Required quantity of feedstocks [tons year $\left.{ }^{-1}\right]=\frac{\left.\text { Production capacity [million liters year }{ }^{-1}\right]}{\text { Bioethanol conversion factors [liters } \mathrm{kg}^{-1} \text { ] }}$

Proportion to collectable biomass $[\%]=\frac{\text { Required quantity of feedstocks }}{\text { Collectable residue yield }} \cdot 100 \%$ 


\section{Results and Discussion}

\section{Analysis of Historical Bioethanol Production in Thailand}

Tracing back the history of bioethanol in Thailand, as shown in Fig. 2, bioethanol first began being used in the transport sector in 2004 [2, 4]. In 2006, commercialization of bioethanol started through the blending of $10 \%$ ethanol with gasoline that had an octane rating of 95 . This was known as gasohol 95 E10 [2, 54]. In the beginning, bioethanol was introduced not only to act as a substitute for crude oil but also to replace the admixture of methyl-tert-butyl ether (MTBE) in gasoline. In terms of environmental impact, MTBE adversely affected the environment, while ethanol was found to be a suitable MTBE substitute for oxygenating and boosting the octane to enhance engine combustion [106].

There are many reasons why there has been a growing demand for bioethanol. First, gasoline consumption has increased year on year. As presented in Fig. 2, the demand for gasoline increased from 7121 million liters in 2008 to 11,373 million liters in 2018 in line with the rise in imported crude oil. The demand for gasoline in 2018 grew to reach $26 \%$ of the 33,086 kilotons of oil equivalent, the total fuel demand in the transport sector [107].

Next, in 2008, the government promoted the blending of gasoline with a higher ethanol rate of $20 \%$, and a rate of $85 \%$ bioethanol. Certain ratios of bioethanol to gasoline have become mandatory on the market as regulated by an announcement by the Department of Energy Business. This specified three rates of bioethanol mixing: $10 \%, 20 \%$, and $85 \%$, marketed as gasohol E10, E20 and E85, respectively [108]. Furthermore, the consumption rate of bioethanol in the country was higher after the introduction of a policy on lowering the market share of 91-octane gasoline in
2013. Restrictions on selling unmixed 91-octane gasoline increased the demand for bioethanol by $67.7 \%$ in 2014 over 2013 levels.

The cassava and sugarcane used to produce the bioethanol is supplied domestically and is able to meet the country's demand. In 2018, this demand for bioethanol totaled 1514.7 million liters which is equal to 4.15 million liters per day. Currently, there are 26 bioethanol producers on the market, operating by three major input materials: molasses, cassava and a hybrid feedstock made from both types of input materials. In 2018, the largest proportion of the bioethanol (around 2.17 million liters per day) was produced using molasses supplied by sugar factories as a feedstock. The second largest bioethanol producers were plants supplied with fresh cassava or cassava chips, contributing around 1.09 million liters of bioethanol per day. While hybrid plants make up the lowest share, producing around 0.81 million liters per day, this type of plant is a flexible option for industry as it can switch between raw materials [105]. Figure 3 shows the trends of feedstocks as input materials. Over the last 10 years, the proportion of molasses feedstock has been higher than that of cassava, dominating at around $60 \%$ in 2018 .

Cassava and sugarcane are used in several industries. By promoting the government's bioethanol strategy, distribution channels for the agricultural crop can be expanded. This would allow the agricultural products to be distributed to the country's energy and food sectors. This is expected to increase the value of the agricultural products.

Sugarcane production in Thailand is the fourth largest by volume in the world, whereas sugarcane exports, amounting to 11.5 million tons in 2018, are the second largest in the world behind Brazil [109, 110]. This is a major economic crop in Thailand being used domestically in the sugar, alcohol, and beverage production industries. Meanwhile, Thailand is the third largest producer of cassava, comprising $10.6 \%$ of global production in 2017 [109]. Compared to
Fig. 2 Development of imported crude oil and gasoline sales in Thailand between 1992 and 2019, based on data from the Department of Energy Business [2]

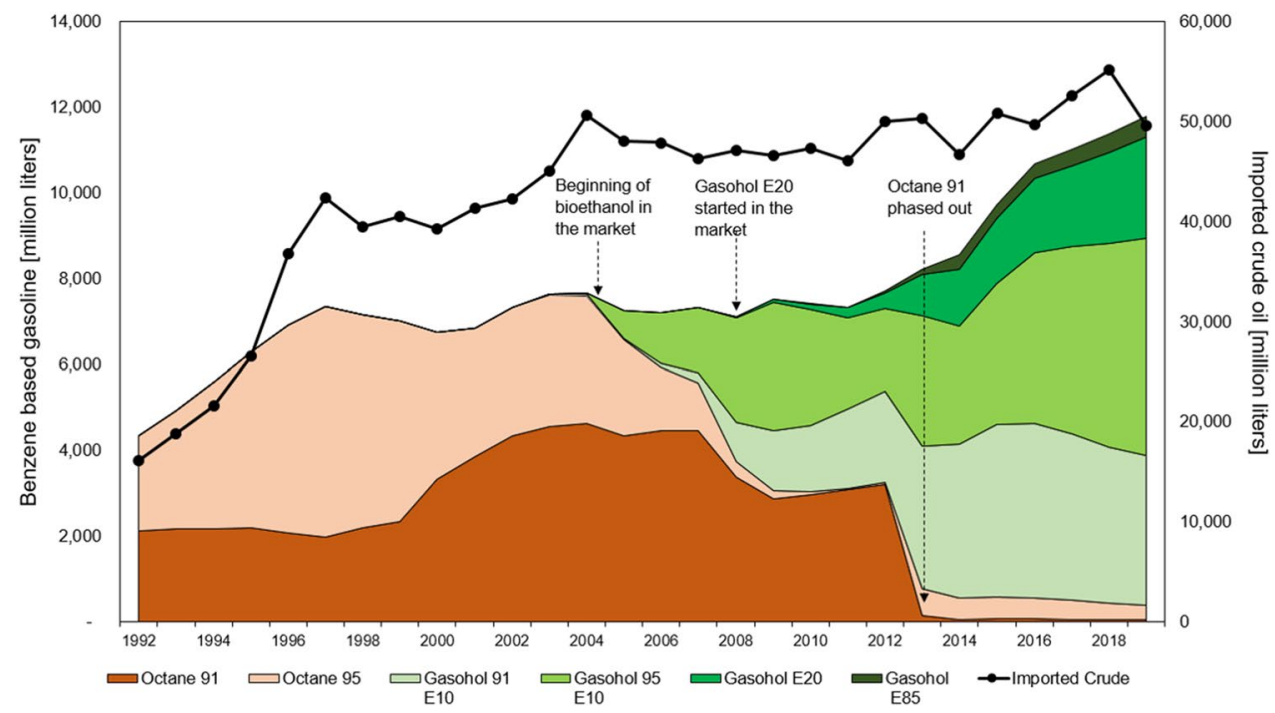


Fig. 3 Development of the feedstock distribution for bioethanol production in Thailand compared to demand over the last ten years (adapted from data from DEDE) [105]

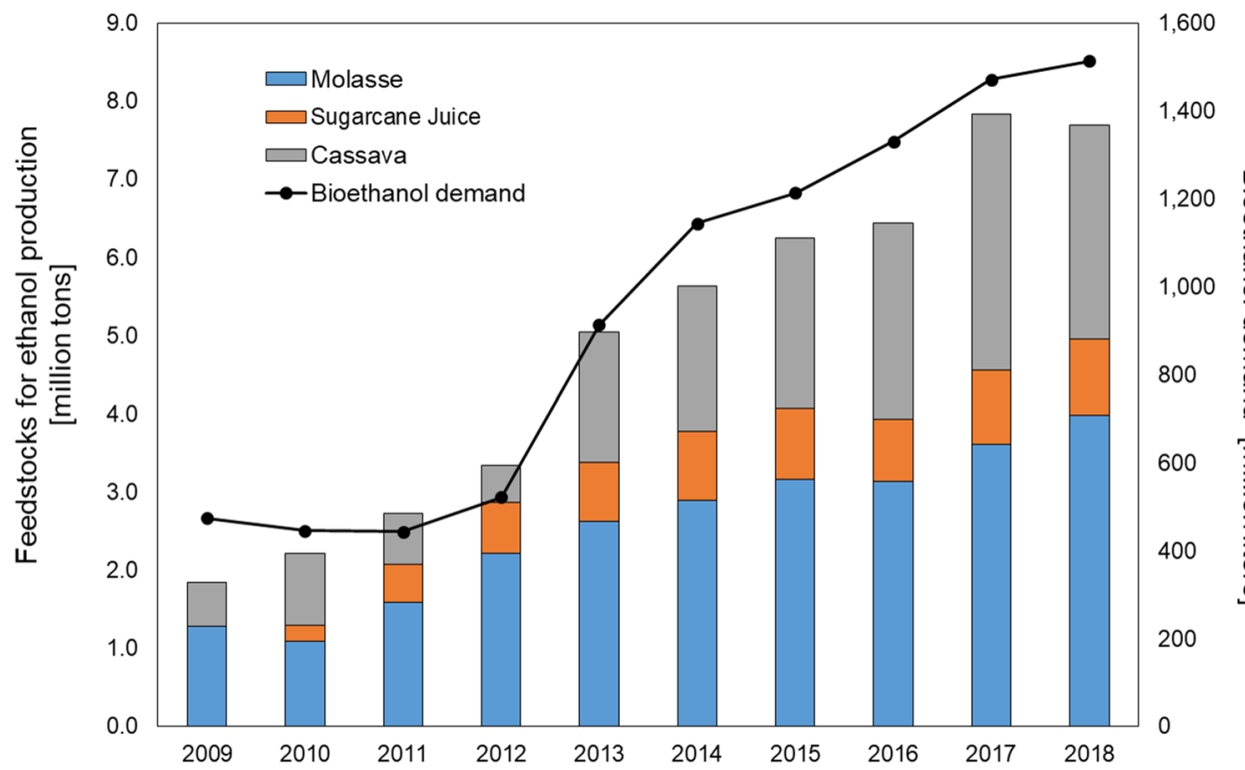

feedstocks derived from sugarcane, cassava has a broader application in industry being used to produce starch, sweeteners, organic acid, sugar alcohols, alcohols and poultry feed [111]. The benefit of using cassava as a feedstock is that it can be stored as a dried material, extending the material's shelf life. Dried cassava chips are at a particular advantage when it comes to logistic efficiency compared to other highmoisture feedstocks and they can be supplied to the bioethanol industry throughout the entire harvesting season [112].

Between 2008 and 2018, the production of sugarcane and cassava increased by $91 \%$ and $9.1 \%$ respectively. In its aim to expand crop production to meet domestic demands, the government committed to promoting sugarcane cultivation and production increased from 71.1 million tons in 2008 to 135.9 million tons in 2018 [46]. For cassava cultivation, Thailand has improved cultivating technology to enhance the crop yield per area from the past productions, achieving around $17.4-27.3$ tons per hectare [109, 113]. However, as can be noted in Fig. 4, the crop yields per area did not improve during these 10 years, and even declined in 2018 compared to 2008. Instead, the increase in crop production resulted in larger areas required for cultivation. Thus the cultivation areas have expanded in line with production, meaning that increased sugarcane and cassava production is achieved on larger cultivation areas. One of the causes is associated with the agricultural production process, which relies on seasonal weather and varies according to regional conditions such as soil quality [114]. Looking at past events, productivity
Fig. 4 Change in area for cultivating conventional feedstocks compared to crop yields (production per area)

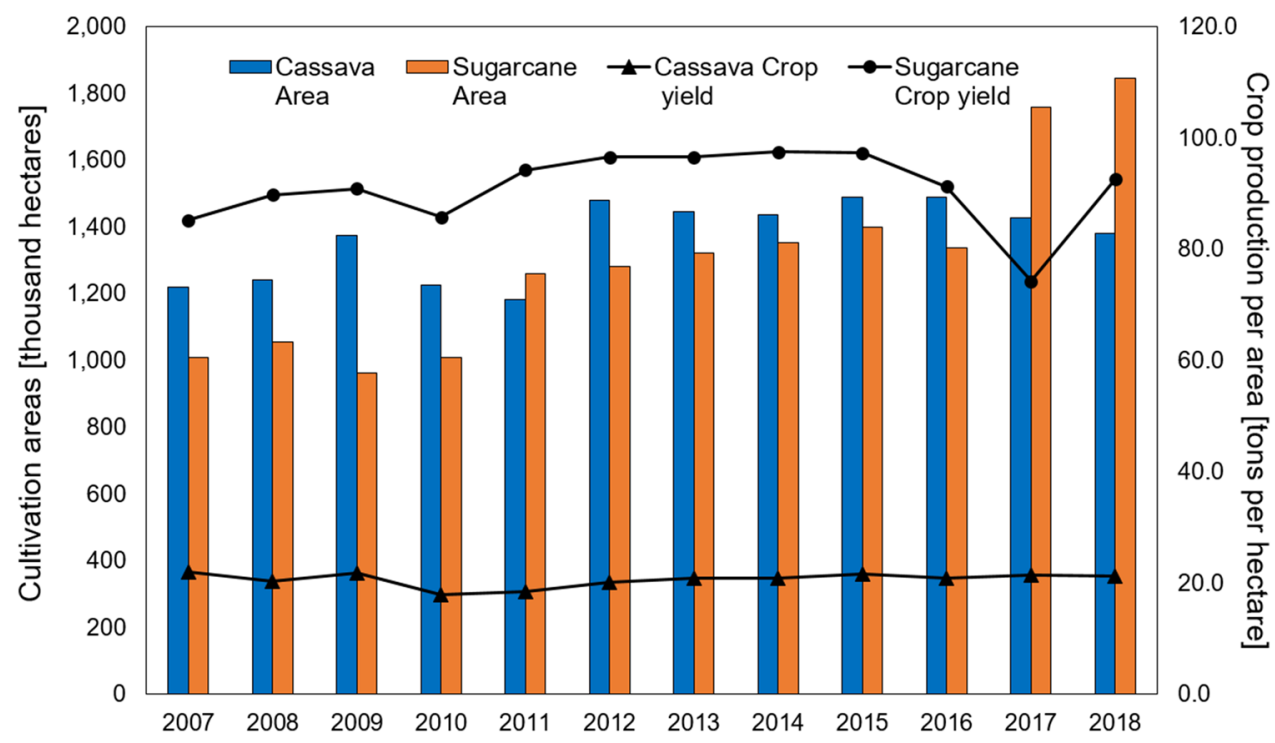


declined significantly in 2017 because of a severe drought for plantations that were mainly supplied by natural rainfall rather than irrigation systems [115].

With regard to future scenarios, bioethanol consumption in Thailand is expected to grow in relation to the energy demand of the transport sector, accounting for more than three-quarters of the total energy consumption $[1,116,117]$. One more significant driver which supports an increase in bioethanol is a planned benchmark in the AEDP to raise the proportion of alternative energy by $25 \%$, and the volume of ethanol supply to 11.3 million liters per day by 2036 . In order to meet supply, the production of sugarcane feedstocks will need to increase from 112.0 million tons per year to 182.0 million tons per year, while crop yields of cassava will need to increase from 2.0 million tons per year in 2015 to 5.7 million tons per year by 2036 [7]. The volume of cassava and sugarcane cultivation will have to increase if the crop yields are to remain the same. Accordingly, a rise in the amount of feedstock has been found to be inevitably linked to land use change $[14,118]$.

\section{Potential of Biomass Residues in Thailand and Current Status of Utilization Rates}

The major crop residues analyzed in the current study were established based on the 2013 database, crop production, agricultural residues and cultivation areas, as summarized in Table $4[46,47,48]$. Sugarcane indicated by far the highest crop production and residue generation. This was followed by rice crops and residues. Despite the low biomass yield per area, rice cultivation occupied the largest area of agricultural land in the country. This was supported by the fact that rice paddies accounted for more than 50\% of total agricultural land [119]. The third largest crop for biomass generation is palm, which is a vital crop for biodiesel in Thailand. In addition, residue generation also significantly has the highest biomass yield per area. Lastly, cassava showed remarkable figures for crop production, resulting in a residue supply that is ranked fourth.

Table 4 lists the crops with the most potential based on data from a statistical report written in 2013. Of these, this study selected the top four crops, namely sugarcane, cassava, rice and palm. The four major types of residue consist of a variety of biomass as described in Table 5. Prior to the
Table 4 Major agricultural crops, biomass generation, cultivation area and biomass yield per area from statistical reports in 2013 [46-48]

\begin{tabular}{llllll}
\hline Ranking & Type of crop & $\begin{array}{l}\text { Biomass genera- } \\
\text { tion [tons year }\end{array}$ & $\begin{array}{l}\text { Crop production } \\
\text { [tons year }{ }^{-1} \text { ] }\end{array}$ & $\begin{array}{l}\text { Cultivation area } \\
\text { in 2013 [ha] }\end{array}$ & $\begin{array}{l}\text { Biomass yield per } \\
\text { area [tons ha }\end{array}$ \\
\hline 1 & Sugarcane & $45,043,010$ & $113,262,163$ & $1,612,484$ & 27.9 \\
2 & Rice & $27,150,897$ & $37,856,470$ & $12,506,752$ & 2.2 \\
3 & Palm & $27,068,920$ & $12,434,520$ & 718,259 & 37.7 \\
4 & Cassava & $16,322,873$ & $30,227,542$ & $1,445,964$ & 11.3 \\
5 & Maize & $10,530,682$ & $4,876,180$ & $1,188,242$ & 8.9 \\
6 & Para rubber tree & $7,003,936$ & $4,192,962$ & $3,711,067$ & 1.9 \\
7 & Coconut & 878,729 & $1,010,033$ & 207,968 & 4.2 \\
\hline
\end{tabular}

Table 5 Biomass from agricultural crops, origin of sources and examples of utilization

\begin{tabular}{|c|c|c|c|c|}
\hline Crops & Collectable biomass & Origin of sources & Examples of utilization & References \\
\hline \multirow[t]{2}{*}{ Sugarcane } & Bagasse & Sugar milling process & Animal feed, paper pulp, particle board, fuel for steam boilers & {$[54,124,125]$} \\
\hline & Leaves and tops & Harvesting process & Animal feed, paper pulp, particle board & {$[130]$} \\
\hline \multirow[t]{4}{*}{ Cassava } & Stems, stalks, leaves & Harvesting process & Not widely utilized & - \\
\hline & Rhizomes & Harvesting process & Biochar, bio-oil & {$[67]$} \\
\hline & Peels & Starch industry & Fertilizer, cattle fodder & [139] \\
\hline & Cassava pulp & Starch industry & Biogas & {$[135,136]$} \\
\hline \multirow[t]{2}{*}{ Rice } & Husk & Harvesting process & $\begin{array}{l}\text { Fuel pellets, silica, activated carbon, ash, cosmetics, construction } \\
\text { materials }\end{array}$ & {$[54]$} \\
\hline & Straw & Harvesting process & Fertilizer, mulch, heating fuel, electricity generation, steam boilers & {$[150,151]$} \\
\hline \multirow[t]{4}{*}{ Palm } & Empty fruit bunches & Milling process & Fuel for heat or electricity, fertilizer & {$[163-165]$} \\
\hline & Mesocarp fibers & Milling process & Mulch, cattle fodder & {$[159,160]$} \\
\hline & Palm kernel shell & Milling process & Biochar and bio-oil & {$[75,161]$} \\
\hline & Palm fronds and leaves & Plantation area & Fertilizer & {$[74,96]$} \\
\hline
\end{tabular}


quantitative analysis step, current practices for utilizing the four selected types of crops were reviewed in a variety of reference sources due to the fact that biomass is generated in different stages of the crop supply chain and is utilized in many different ways.

\section{Sugarcane Residues}

Sugarcane by-products are usually generated on the sugarcane plantation or are derived from the sugar manufacturing process. The by-products obtained on the plantation include several types of residual biomass, such as cane stalks, tops, fresh leaves, dry leaves and dead leaves. Meanwhile, bagasse and molasses are the major by-products of the sugar milling process and account for around 30\% of the biomass from dry biomass [47, 53, 54]. In addition to bagasse, waste from the sugar milling industry, including vinasse and bagasse fly ash, have been studied in the anaerobic co-digestion process in biomethane production by installing biogas in the system [119]. Currently, this crop has contributed to a broad range of valuable products in addition to the production of sugar.

Sugarcane bagasse is a fibrous biomass which is generated in the sugarcane mill as a by-product of cane juice crushing. Bagasse is also the largest amount of residue in the agricultural sector in Thailand [47]. Currently, this type of material has been actively utilized in the sugar refinery as a fuel for steam boilers that power the turbine generator, knife, shredder, and sugar mill [120]. By this added value, it is possible to improve the energy efficiency of sugar production in the production process. In some cases, there is a surplus of in-house generated electricity, which can be sold to national grids.

Due to its strong fibrous but flexible structure, bagasse is used in pulp manufacturing. It can be made into paper, containers, or be used as a plastic substitute [54, 121-125]. Recently, the use of bagasse to produce polyhydroxybutyrate (PHB) and polyhydroxyalkanoates (PHA) has also been explored, providing similar properties as the fossil fuelbased polymer [126-128].

Leaves and cane tops are residues know as cane straw that can be collected from cultivation areas. Thus far, unused sugarcane straw is commonly burned on the field by farmers to prepare for the next round of cultivation [12]. For every ton of dry sugarcane produced, around $250-300 \mathrm{~kg}$ of sugarcane straw has been generated in the field [47, 57]. Even though the biomass volume of sugarcane leaves and tops is lower than that of bagasse, the water content is slightly lower, leading to a higher density of dry biomass yield. Dry leaves contain more cellulose, hemicellulose and lignin, but have a lower water content compared to the green tops [129].

Sugarcane tops and leaves can be used as a feedstock in bioethanol production. However, in contrast to a high nutrient content in the green tops, the dry leaves are relatively more suitable for bioenergy production [83]. Rich nutrients such as nitrogen $(\mathrm{N})$, phosphorus $(\mathrm{P})$ and potassium $(\mathrm{K})$ are specifically found in the green tops, providing benefits for use as fodder for ruminants and as a fertilizer [130]. Dry leaves and tops are utilized as a fuel in generating internal power [131]. In some cases, sugarcane straw is intentionally left on the field to cover the surface of the soil. Used in this way, it is beneficial in that it protects the soil from erosion, generates higher nutrients on the surface of the soil and leads to a lower consumption of inorganic fertilizers $[132,133]$.

\section{Cassava Residues}

Cassava residues are considered more favorable in comparison to other kinds of biomass on account of starch contents. The cassava waste from starch factories, especially cassava pulp and peels, has a high starch content, which offers the advantage of being able to utilize both the starch and the cellulose after the hydrothermal pretreatment process [60]. Meanwhile, the parts with a low starch content, such as the cassava stalks, cassava leaves, and rhizomes, are by-products generated on farms and in the refinery process that could be utilized as a source of lignocellulose.

Among the expected by-products, cassava pulp produces the highest proportion of biomass during starch production, accounting for around $10 \%-30 \%$ of the total weight of wet biomass. Owing to its high starch content, comprising around $50-70 \%$ of dry biomass, cassava pulp can contaminate the environment $[60,134]$. In this regard, several studies have used anaerobic fermentation to treat cassava pulp during the production of biomethane $[135,136]$. At the same time, the high starch content provides an opportunity for bioethanol conversion. The advantage of utilizing cassava pulp is that it can be pretreated in a simpler way; for instance, a hydrothermal pretreatment can be performed instead of applying acid hydrolysis [60]. Bioethanol production from cassava pulp is a promising technology that can be installed alongside the existing tapioca production [137].

Cassava peel is generated during the cassava cleaning process and consists of a periderm and cortex [138]. First, the outer part of the cassava is peeled off to remove soil and sand since the material obtained during this step does not provide favorable biomass that can be used further. After removing the outside layer, the cortex can be collected. This part is more favorable since it contains less soil and is of a higher quality so it can be used in cattle fodder [139].

Cassava rhizomes are a non-edible biomass that can be gathered from the cassava fields. This biomass contains a substantial amount of cellulose and hemicellulose. Although this type of biomass is abundant on farms in Thailand, it has not contributed widely to the production of bio-based products. Currently, rhizome residues from the pyrolysis process can be used in biochar production. Cassava rhizomes have 
also been examined with respect to their efficacy in bioethanol fermentation, confirming their potential as a feedstock [140].

\section{Rice Residues}

Rice is a traditional food staple in Thailand. The annual production of rice covers export volumes, allowing Thailand to be the second major exporting country of rice in the world [141]. By-products from paddy fields, such as rice straw and rice husks, are generated on a regular basis. This abundant biomass has received more attention in the development of bio-based products [142-144]. In Thailand, residues from paddies are conventionally used in animal fodder and fertilizers, while the surplus waste is mostly eliminated by open burning in order to prepare for the cultivation of the next crop [145]. Rice straw, which accounts for $48 \%$ of the generated residues, is most widely treated in Asian countries in open-field burning [49]. However, in order to prevent the open burning of post-harvest rice, new technology has now been introduced, such as baling machines, in order to change farming practices and waste collection [146]. The mechanized collecting system for gathering and baling rice straw can be beneficial in that it reduces labor and transport, which consequently lessens the environmental impact and increases the opportunity to utilize waste [147].

Rice straw is a collectable by-product that remains on the farm. This biomass is, however, sometimes collected by the locals to use as fuel for cooking. More rice straw biomass is produced than rice husk biomass, as the residue-to-crop ratio varied between 0.7 and 1.4 of rice production depending of the variety and the system for harvesting paddy stubble [148]. Based on data on both primary and secondary rice production in 2018, Thailand produces an estimated 26.2 million tons of rice straw per year on average [46]. According to a report issued by the Rice Department, around 18-29 million tons of residual rice straw was managed by burning it as paddy stubble on the field [148]. This has become a serious issue, causing air pollution due to the emission of gas and small dust particles [149].

The most common ways to utilize rice straw in Thailand is as a fertilizer, as mulch for growing straw mushrooms, as a heating fuel, and as a feedstock for electricity generation [150-152]. In the past 10 years, Thailand has encouraged the use of rice straw in energy production to some extent, mainly focusing on heat and power generation, for example, in industrial boilers [21]. However, of the possible conversion pathways of rice straw, bioethanol conversion is considered to be sustainable since it produces the best life cycle assessment results [145]. Nonetheless, the development of rice straw for bioethanol production is inevitably hindered by its silica content, which inhibits the fermentation process and is of higher proportions than in other types of biomass
$[153,154]$. A conversion efficiency of $260 \mathrm{~L}$ of ethanol per ton of dry rice straw has been reported by Delivand et al. [36].

Rice husks are the part of biomass generated from the process of rice milling. It is the outer layer of the grain, which is separated from the seed. Rice husks have a wide range of uses in Thailand and are typically used as a fuel, a fertilizer, and in silica-based materials. Rice husks are primarily used to supply energy in the milling process through direct combustion or gasification [54]. Rice husks have been reported to generate $1 \mathrm{MW}$ of electricity from 9800 tons of biomass [54]. They typically contain high levels of silica and lignin which are the main mineral components forming the hard material. The proportion of silicon oxide is around $86.7 \%$, which differs from other types of biomass [144]. The ash derived from combusting rice husks in steam boilers can be mixed with original concrete to strengthen the durability of the cement [155]. In addition, the high proportion of silica is considered to be a potential material for higher valued applications, for instance, the production of amorphous silica can be used in photovoltaic panels or $\mathrm{Li}$-ion batteries $[143,156]$.

\section{Palm Residues}

Palm is an economic crop that has many different applications. Thailand has increased its palm production and is ranked the third-largest producer behind Indonesia and Malaysia. Palm oil production climbed from 8.2 million tons in 2009 to 15.5 million tons in 2018 due to a rising demand from the domestic and export markets [46]. In terms of domestic sales, palm oil provides the domestic market with a wide range of both food and non-food products. For example, it is used as a cooking oil and in the oleochemical industry, and as a fuel in the transportation sector [157]. An important factor that drives demand in the domestic market is the endorsement by the government of a mandatory mixing of diesel with methyl ester derived from palm oil. In 2019 , biodiesel began being subjected to a $10 \%$ blending, up from $7 \%$ in order to absorb surplus stock on the market $[2,158]$.

Due to the rising palm oil production in the country, residual biomass from palm trees has increased accordingly $[159,160]$. During cultivation, the solid residues from palm trees were not being fully utilized in the system which resulted in the generation of biomass waste. This accounted for around $90 \%$ of the plant in comparison to the proportion of the fruit used to make palm oil. Biomass residues are generated from 2 sources during the production process: cultivation and milling. By-products are produced during the milling process including empty fruit bunches (EFB), mesocarp fibers (MF), palm kernel shells (PKS) and palm 
oil mill effluent (POME). Meanwhile, palm leaves (fronds) and trunks are the biomass generated from cultivation.

The structure of the palm fruits can be categorized into the mesocarp and kernel. In palm oil refineries, residues from milling have become more valuable and developed for higher applications. Palm oil is extracted from the flesh of the mesocarp, leaving behind an unnecessary part known as mesocarp fibers (MF). In general, the mesocarp fibers are commonly used for mulching, livestock feed and as a biofuel for heat or electricity generation $[159,161]$. The palm kernel is a seed protected inside the palm kernel shell (PKS) which is generated when palm oil is extracted from the palm kernel [72]. PKS can be converted into a form of briquettes derived from the gasification process. This, in turn, can be utilized as a fuel, reducing the energy required by the palm oil production plant [162].

The majority of palm waste is from the leaves (fronds) [163], while the second-largest amount of palm waste is from empty fruit bunches (EFB). Due to the physical characteristics of EFB, e.g., a moisture content of more than $50 \%$, it is used in mulch production rather than as a fuel in the steam boiler. The rich nutrients in EFB make it advantageous for the soil and reusing this type of biomass on the plantation is thought to enhance crop yields [163-165].

As one of the prospective scenarios for increased biofuel production, a higher demand for lignocellulosic biomass could possibly impact biomass supply for other utilization purposes, such as animal feed, household fuel or electricity generation. In order to tackle trade-offs from a scenario where an immense amount of biomass would flow into the bioenergy sector, the strategy requires an adequate method of biomass management, particularly in the case of Thailand. Even though agricultural residues have been deployed in several applications, the leftover agricultural residues generated in Thailand are presently not being exploited to their maximum potential $[12,149]$. Currently, around $50 \%$ of rice residues are managed in rice paddies through field burning or left unutilized in the fields [166]. The biomass collection efficiency is primarily limited by the fact that many farmers lack proper machinery for the baling process which would alleviate costs and reduce labor intensity during the gathering and transport process. It encourages farmers to conduct open field burning to save time $[152,167]$. Thus, systematic management of biomass is a crucial measure for dealing with unexploited leftover biomass.

In addition to improving biomass collection efficiency, policies can play an important role in balancing the tradeoffs on many levels across sectors. In terms of economic relief, establishing financial measures, such as subsidies, can incentivize trading systems that have fair prices for foodfeed-fuel biomass and possibly encourage more industrialization of materials [168]. Moreover, a government strategy at the national level could also shape a policy scheme to address a substantial development plan by prioritizing residue utilization for food, feed and fuel purposes [169]. This could be used as a guideline for stakeholders in biomass development in order to create more advantages for maximizing values from appropriated usage.

In addition to strategic policy planning, technological improvements encourage circular material flows by reutilizing by-products. Bagasse, which was originally a fuel needed in the production of electricity to operate sugar mills, could be replaced by vinasse [170]. Substituting bagasse and straw with other by-products demonstrates that it is possible to incorporate technology to support the biomass shift to second-generation bioethanol production. Moreover, a small-scale bioethanol configuration also would allow a biogas fermentation process to be incorporated into bioethanol production. This would become a promising solution to supply output energy, such as biogas and electricity as byproducts [33]. Supplying the generated output energy from biorefinery plants to local communities would optimize the biomass that would be supplied as fuel to households.

The decentralized production model can assist in addressing the issue concerning the potential risks that may occur from excessive demand in the bioenergy sector in the future. A decentralized system enhances biomass management by offering the possibility of mixing input materials, which is beneficial for the supply chain [171]. Compared to largescale biorefineries, the distributed plants can avoid bulk stocks of biomass, which are amassed for only one production unit [172]. With respect to flexibility and reducing biomass loss, it is more advantageous when the input materials are not only used for biofuel production. It enables agricultural residues to be extended to other production chains, including essential commodities [34]. At the same time, the decentralized model can also encourage engagement between energy producers and farmers to achieve better business relationships [42].

\section{Regional and Provincial Distribution of Agricultural Residues in Thailand}

In the first step of the study, data on the total availability of the selected agricultural crops-sugarcane, cassava, rice and palm - and their cultivation areas were collected from statistical sources. This data is summarized in Table 6. By using the factor of residue-to-crops ratio from Table 1, which was gathered from several scientific sources, the study was able to estimate residue production and residue production per area.

Biomass derived from sugarcane, including bagasse, tops and leaves, was significantly highest at 74.2 million tons with a production per area of 40.2 tons per hectare. Following that, palm residues from palm plantations were estimated at 38.2 million tons, while the yields per area were 
Table 6 Statistical crop production and residue estimations compared to actual amount of feedstocks for bioethanol production in Thailand in 2018

\begin{tabular}{|c|c|c|c|c|}
\hline Crops and residues & $\begin{array}{l}\text { Crop production [tons } \\
\text { year }^{-1} \text { ] }\end{array}$ & Cultivation area [ha] & $\begin{array}{l}\text { Residue generation [tons } \\
\text { year }^{-1} \text { ] }\end{array}$ & $\begin{array}{l}\text { Residue production } \\
\text { per area [tons } \text { ha }^{-1} \text { ] }\end{array}$ \\
\hline Sugarcane [48] & $131,717,046$ & $1,846,808$ & & \\
\hline Bagasse & & & $41,315,247$ & 22.4 \\
\hline Tops and leaves & & & $32,929,262$ & 17.8 \\
\hline Subtotal & & & $74,244,509$ & 40.2 \\
\hline Cassava [46] & $29,368,185$ & $1,379,885$ & & \\
\hline Pulp & & & $7,007,774$ & 5.1 \\
\hline Peels & & & $8,125,198$ & 5.9 \\
\hline Stem and leaves & & & $3,524,182$ & 2.6 \\
\hline Rhizome & & & $10,132,024$ & 7.3 \\
\hline Subtotal & & & $28,789,178$ & 20.9 \\
\hline Rice [46] & $32,363,299$ & $11,423,342$ & & \\
\hline Straw & & & $25,785,458$ & 2.3 \\
\hline Husks & & & $7,119,926$ & 0.6 \\
\hline Subtotal & & & $32,905,384$ & 2.9 \\
\hline Palm [46] & $15,534,984$ & 940,500 & & \\
\hline Empty fruit bunches & & & $3,189,850$ & 3.4 \\
\hline Fiber & & & $2,338,015$ & 2.5 \\
\hline Shells & & & $1,465,467$ & 1.6 \\
\hline Leaves and fronds & & & $31,178,713$ & 33.2 \\
\hline Subtotal & & & $38,172,045$ & 40.7 \\
\hline Total & 208,983,514 & & 174,111,116 & \\
\hline \multicolumn{5}{|c|}{$\begin{array}{l}\text { Actual quantities of feedstocks for } \\
\text { bioethanol in } 2018 \text { [47] }\end{array}$} \\
\hline Molasses & & & $3,988,092$ & \\
\hline Sugarcane & & & 964,346 & \\
\hline Cassava & & & $2,742,039$ & \\
\hline
\end{tabular}

the highest value among the studied biomasses, at 40.7 tons per hectare. Next, the third highest amount of residues were from rice, at 32.9 million tons with a production per area of 2.9 tons per hectare. Despite rice straw having the highest residue-to-crop ratio, estimated residue production per area was rather low since the area required for rice cultivation was relatively large, resulting in a low rate of yield per hectare. Lastly, cassava generated 28.8 million tons of agricultural residues as by-products. Although residues derived from cassava are lower on average than other types of residues, the residue production per area turned out to be higher than that of rice, accounting for 20.9 tons per hectare.

The distribution of agricultural residues was categorized into four major regions: northern, northeastern, central, and southern Thailand, as presented in Fig. 5. Biomass availability differed in each particular region with respect to variation and proportion, suggesting the results corresponded to the geographical features. Firstly, the northern region had the lowest total amount of residues, possibly due to the fact that the northern region is covered in mountains and has a longer dry season than the other regions. Although rice residues have the highest potential in this area, they contributed to only around 3.0 million tons.

On the other hand, the most residues are produced in the northeastern and central regions, with nearly similar proportions of crop residues. Sugarcane residues, including bagasse and sugarcane straw (tops and leaves), demonstrated the most significant results, totaling 36.8 and 36.6 million tons in the northeastern and the central regions respectively. The provinces in northeastern and central Thailand produced similar data on rice and cassava residues. The northeastern area produced more cassava than rice at 19.3 and 13.8 million tons respectively, whereas in the central region, rice and cassava production reached 15.7 and 9.0 million tons respectively.

Lastly, southern Thailand produced a distinct type of residue. Most of the residues came from palm plantations, totaling around 34.3 million tons. Due to the fact that this region of Thailand is very humid, palm plantations are more suitable here than in other areas. The majority of residues consist of leaves and fronds from palms, with expected amounts of 34.3 million tons. In addition to the palm residues, small 


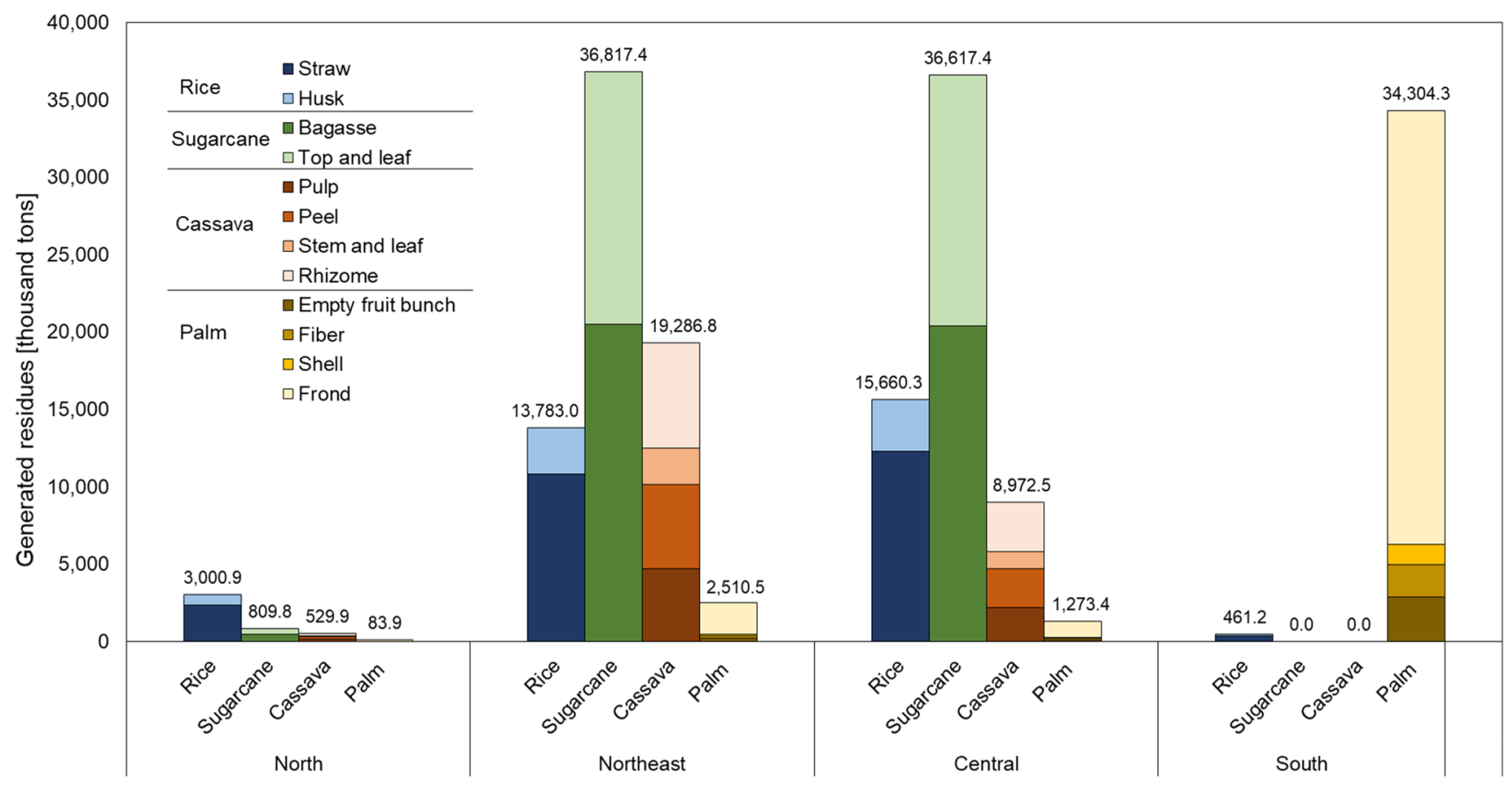

Fig. 5 Distribution of the regional agricultural residues from rice, sugarcane, cassava and palm as determined by this study

amounts of rice straw were also available in southern Thailand, totaling 0.46 million tons.

In addition to the quantitative data generated by region, the four types of residues were also broken down by province. The distribution of residues on a provincial scale is illustrated in Supplementary Fig. 1, which shows the total production of residues per province. In addition, the density of biomass per area was calculated to generate the geographical results exhibited in Supplementary Fig. 2. The results demonstrate that the total quantity of generated residues per province did not correspond exactly to the information on biomass yield per area.

Looking at the total quantity of each type of agricultural residue on a provincial scale (Supplementary Fig. 1), the GIS results confirmed that a substantial volume of sugarcane, cassava and rice residues was generated in the central and northeastern provinces. The significantly large volumes of sugarcane residues ranged from 4.0 to 5.1 million tons. The highest amount of sugarcane residue was produced in Kamphaeng Phet province in the central region and amounted to 5.1 million tons. Meanwhile, highly intensive areas produced 4.2-5.2 million tons of biomass from cassava residues, whereby Nakhon Ratchasima in the eastern region achieved the highest amount of cassava residues at $5.2 \mathrm{mil}-$ lion tons. The high production of rice residues from rice plantations were scattered over wider areas of the north and central regions. The highly concentrated volume of generated rice residues ranged between 1.0 and 1.9 million tons. The largest producer of rice residues was Nakhon Sawan, a province in the central region that generated a total of 1.9 million tons of rice biomass.

In contrast, a different result can be observed with respect to palm residues. Biomass derived from palm plantations is significant in the southern region where there was only a very marginal generation of other kinds of studied biomass. The largest amount of palm residues produced was 7.2-9.0 million tons. Most of the generated palm residues were estimated to come from Surat Thani province and totaled around 9.0 million tons.

When investigating available residues per area (Supplementary Fig. 2), the study obtained surprising results for residue density, which resulted in different outcomes compared to total availability. Even though palm plantations produced the lowest amount of crops, they achieved the highest residue yields per area. The high residue density was identified in the southern and lower central regions where the farm areas supplied 45.4-56.7 tons of palm residue per hectare.

The second highest yields per area were for sugarcane residues, amounting to 32.8-41.0 tons per hectare. High residue densities predominantly occurred in the provinces in the central and northeastern regions. Cassava residues showed an identical distribution. High production yields of this type of residue took up more extensive areas compared to that of sugarcane, covering the central, northeastern and northern regions of Thailand. Exhibiting the third highest yields per area, cassava plantations contributed the largest density of around 21.4-26.7 tons per hectare. 
Despite the fact that crop production is higher for rice than for cassava, the generated yield of rice residues resulted in the lowest density, accounting for only 2.7-3.3 tons per hectare. Comparing this with the result of rice residues per province, the high density of rice residues per area showed a different pattern of spatial distribution, indicating the highest density areas in some parts of southern, central and northern Thailand.

Due to the scattered locations of crop production in different regions, generating geographic information on biomass helps determine where resource supplies are feasibly located. The geographical allocation of resources is regarded as fundamental for the further assessment of second-generation bioethanol, taking into account the feasibility of commercialization, such as the optimal distance from farms to production plants.

\section{Estimation of Regional Bioethanol Potential in Thailand by Region and Province}

Following the method proposed in Eqs. (3-7), ethanol conversion factors were calculated for all residues included in the study. The values for ethanol to dry biomass were found to range between 0.15 and 0.55 liters $\mathrm{kg}^{-1}$, while pulp had the highest conversion factor.

As summarized in Table 7, the results suggested that, among the studied crop variations, the highest amount of bioethanol production can be anticipated for the sugarcane residues generated in 2018, reaching around 9427.2 million liters per year. Residues derived from rice cultivation, which could theoretically produce 4649.4 million liters per year, came in second for expected bioethanol production. This was followed by the residues from cassava and palm cultivation, which were estimated to achieve a maximum bioethanol production of 3432.5 and 2704.5 million liters per year, respectively.

A comparison of each type of residual biomass found that the expected volume of bioethanol was determined by the quantity of generated residues and the ethanol conversion factor. As a result, sugarcane tops and leaves produced the highest amount of estimated bioethanol at 5183.1 million liters per year. This was followed by the second highest volume generated from sugarcane bagasse, producing 4244.1 million liters per year.

Similarly, in the case of rice residues, rice straw affirmed the link between generated volumes and bioethanol conversion and ranked third for potential bioethanol among the
Table 7 Summary of bioethanol estimation from total agricultural residues in 2018 as determined by this study

\begin{tabular}{|c|c|c|c|c|}
\hline Agricultural residues & $\begin{array}{l}\text { Agricultural resi- } \\
\text { dues (dry biomass) } \\
\text { [tons year }{ }^{-1} \text { ] }\end{array}$ & $\begin{array}{l}\text { Ethanol conversion } \\
\text { factor [liters } \mathrm{kg}^{-1} \text { ] }\end{array}$ & [million liters year $\left.{ }^{-1}\right]$ & $\begin{array}{l}\text { Expectable } \\
\text { ethanol } \\
\text { yield per } \\
\text { day } \\
{[\text { million lit- }} \\
\text { ers day }^{-1} \text { ] }\end{array}$ \\
\hline \multicolumn{5}{|l|}{ Sugarcane } \\
\hline Bagasse & $20,488,231$ & 0.21 & $4,244.1$ & 11.6 \\
\hline Tops and leaves & $26,346,977$ & 0.20 & $5,183.1$ & 14.2 \\
\hline Subtotal & $46,835,208$ & & $9,427.2$ & 25.8 \\
\hline \multicolumn{5}{|l|}{ Cassava } \\
\hline Pulp & $1,484,480$ & 0.55 & 820.6 & 2.2 \\
\hline Peel & $2,369,849$ & 0.30 & 717.2 & 2.0 \\
\hline Stem and leaves & $1,686,948$ & 0.18 & 306.4 & 0.8 \\
\hline Rhizome & $7,136,744$ & 0.22 & $1,588.4$ & 4.4 \\
\hline Subtotal & $12,678,021$ & & $3,432.5$ & 9.4 \\
\hline \multicolumn{5}{|l|}{ Rice } \\
\hline Straw & $17,051,924$ & 0.21 & $3,561.6$ & 9.8 \\
\hline Husk & $6,436,413$ & 0.17 & $1,087.8$ & 3.0 \\
\hline Subtotal & $23,488,337$ & & $4,649.4$ & 12.8 \\
\hline \multicolumn{5}{|l|}{ Palm } \\
\hline Empty fruit bunch & $1,151,695$ & 0.23 & 269.5 & 0.7 \\
\hline Fiber & $2,162,898$ & 0.20 & 433.1 & 1.2 \\
\hline Shell & $1,362,103$ & 0.15 & 204.8 & 0.6 \\
\hline Leaf (frond) & $8,574,146$ & 0.21 & $1,797.0$ & 4.9 \\
\hline Subtotal & $13,250,842$ & & $2,704.4$ & 7.4 \\
\hline Total & $96,252,408$ & & $20,213.5$ & 55.4 \\
\hline
\end{tabular}


selected types of biomass. Such residues could potentially be converted to 3561.6 million liters of bioethanol per year. The study also confirmed similar results in the case of cassava and palm as the highest yields of bioethanol were achieved from cassava rhizomes and palm leaves at 1588.4 and 1797.0 million liters per year respectively.

Summing up all analyzed data on residues, the current study estimated a potential of 20,213.5 million liters of bioethanol per year from 174.1 million tons of agricultural residues per year, which is equivalent to 96.3 million tons of dry biomass per year. Approximate supply volumes of bioethanol could be 55.4 million liters per day. Compared to the recent estimation by Heo et al. our study projects significantly higher ethanol production potentials, implying the possibility of obtaining more benefits from existing biomass [44].

The regional distribution of Thailand's bioethanol production potential, totaling 20,213.5 million liters per year, is shown in Table 8. It is notable that northeastern Thailand showed the highest potential for bioethanol production, which is mainly expected to come from sugarcane residues. Similarly, the central region, where the by-products of sugarcane also make up the major part of feedstocks, was estimated to produce the second highest amount of bioethanol.

Residue generation was expected to be lower in the north and south of Thailand than in the northeast and central regions. This is because the southern region has a particularly high concentration of palm plantations. At the same time, bioethanol production in the northern region was expected to be very limited compared to other regions due to a lower levels of crop cultivation.

The calculations in the study and the GIS illustrations in Fig. 6, show that prospective bioethanol production would be concentrated in the northeastern and central provinces.

As summarized in Fig. 7, the top ten crop residues mostly consisted of derivations of sugarcane and cassava. At a glance, the bioethanol results were found to correspond to residue availability since the three highest production volumes are expected in Nakhon Ratchasima, Kamphaeng Phet and Nakhon Sawan. Another noticeable point is that

Table 8 Regional distribution of estimated ethanol potential categorized by type of residue

\begin{tabular}{lrrrr}
\hline Feedstock & \multicolumn{3}{c}{ Bioethanol estimation per region [million } \\
& liters year ${ }^{-1}$ ] & & \\
\cline { 2 - 5 } & \multicolumn{1}{c}{ North } & Northeast & Central & South \\
\hline Sugarcane residues & 102.8 & 4674.9 & 4649.5 & 0.0 \\
Cassava residues & 63.2 & 2299.5 & 1069.8 & 0.0 \\
Rice residues & 424.0 & 1947.5 & 2212.7 & 65.2 \\
Palm residues & 5.9 & 177.9 & 90.2 & 2430.4 \\
Total ethanol estimation & 595.9 & 9099.7 & 8022.2 & 2495.6 \\
[million liters year ${ }^{-1}$ ] & & & & \\
\hline
\end{tabular}

sugarcane residues made up a major proportion of the converted bioethanol and most of these provinces are located in the northeastern and central areas. However, Surat Thani province is the only province where the palm residues are mainly utilized for bioethanol production.

Figure 7 shows that, of the 77 provinces, the study found that Nakhon Ratchasima, a province in northeastern Thailand, was able to potentially produce the highest bioethanol volumes at 1,328.0 million liters per year. The approximated volume of bioethanol in this province was mostly accounted for by cassava by-products, making up $47 \%$ of the total potential volume of bioethanol.

When the existing location of bioethanol production plants (Table 9) operating as "business as usual" in 2019 are compared with the top ten highest estimates for bioethanol production (Fig. 7), it was found that some provinces with high potential have not installed any ethanol production facilities. The results of projected bioethanol production, as presented in Fig. 7, suggest room for investment in production plants, including in Kamphaeng Phet, Udon Thani and Surat Thani. The results for potential bioethanol production in Surat Thani particularly highlight the fact that the southern region of Thailand has hotspot areas where a production facility could prospectively be located, when an enhancement in logistics is taken into consideration.

As of now, bioethanol production plants are mainly located in the central and northeastern regions of Thailand. The 26 production plants currently operating in Thailand are mainly fed with molasses, sugarcane juice or cassava. In some cases, the production plants are able to process both types of materials (hybrid production system). Table 9 shows production capacities of each production plant located in the different provinces, taken from the 2019 ethanol production report [105]. Residue availabilities estimated by this study enabled alternative feedstocks to be chosen from the most generated residues. Alternative feedstocks were calculated for the required input quantity based on production capacity data and ethanol conversion factors. As a result, it was found that most of the production plants can be supplied by agricultural residues, which are available in the provinces in which the plants are located.

After verifying the required feedstocks, the necessary quantity was calculated in relation to the share of collectable biomass within the same provincial boundary. If the values were found to be smaller than or equal to $100 \%$, this signaled that enough residues were on hand to be fed into the bioethanol production plants. The results indicate that the input materials of some production plants could be replaced by abundantly collectable biomass, which differ from the conventionally utilized feedstocks.

Although the required amount of feedstocks can differ depending on the size of the plant, the scenario of alternating 

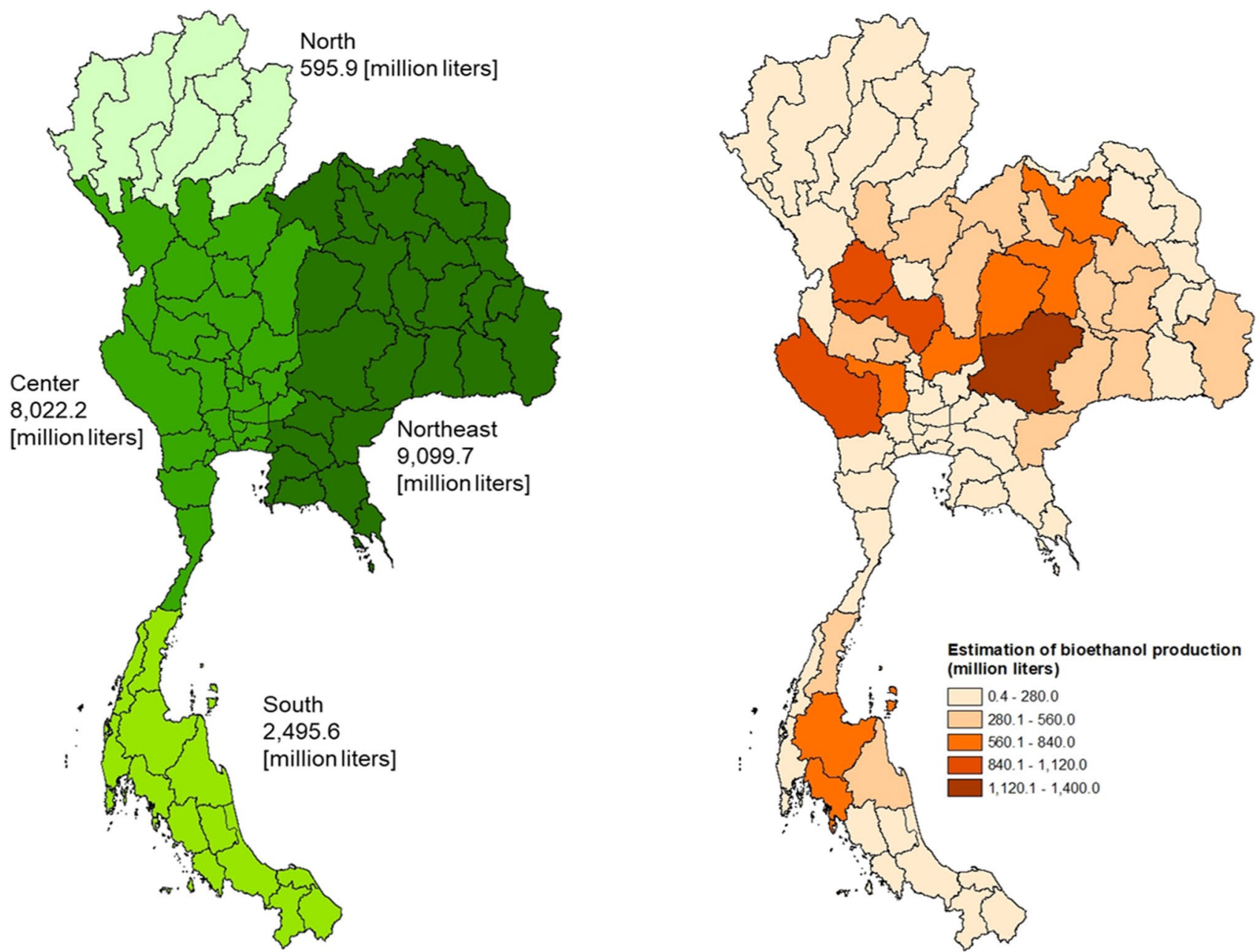

Fig. 6 Annual bioethanol production potential from residues in Thailand by region (left) and by province (right)

Fig. 7 Top ten provinces for annual bioethanol estimation and proportions of available feedstocks

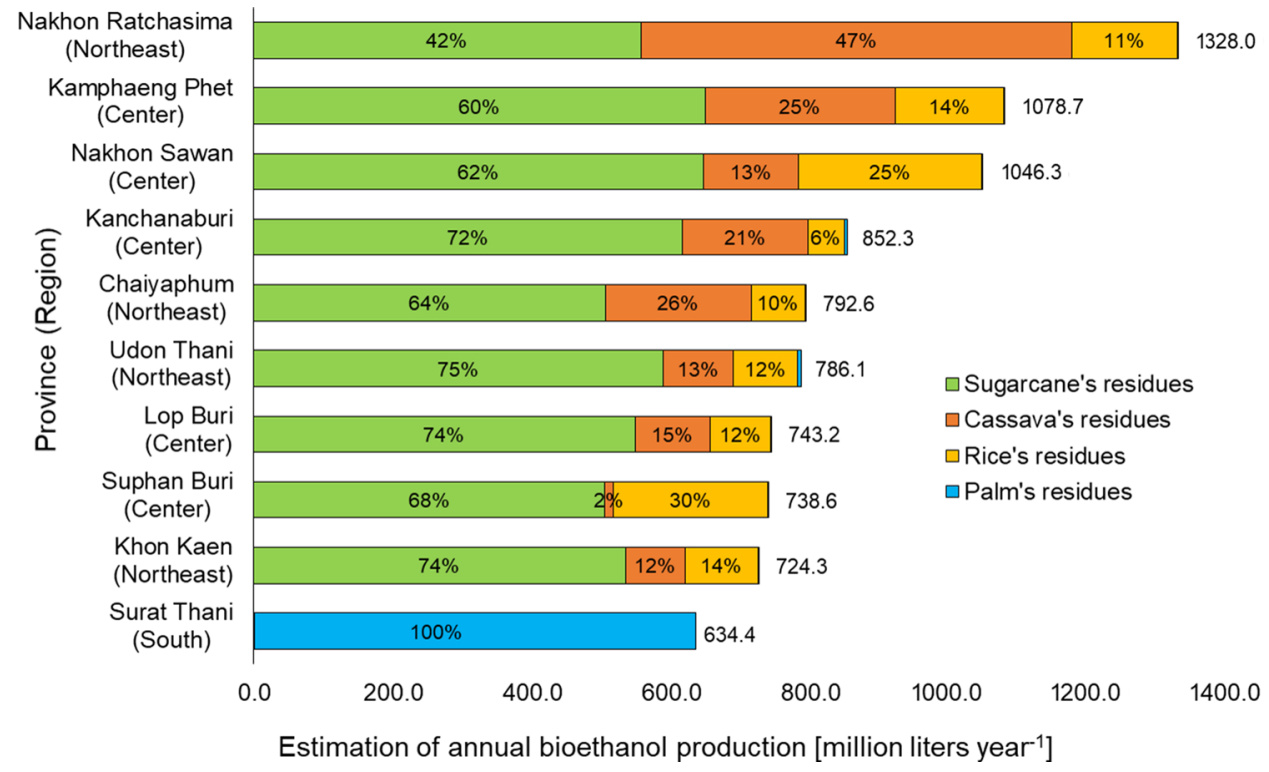


Table 9 Current production capacities by plant in comparison with required amounts and proportions of proposed alternative feedstocks

\begin{tabular}{|c|c|c|c|c|c|c|c|}
\hline Plant no & $\begin{array}{l}\text { Location of } \\
\text { ethanol production } \\
\text { (province) }\end{array}$ & Region & $\begin{array}{l}\text { Production capac- } \\
\text { ity [million liters } \\
\left.\text { year }^{-1}\right][105]\end{array}$ & $\begin{array}{l}\text { Type of } \\
\text { conventional } \\
\text { feedstock }\end{array}$ & $\begin{array}{l}\text { Alternative feed- } \\
\text { stocks (proposed } \\
\text { by the study) }\end{array}$ & $\begin{array}{l}\text { Required feed- } \\
\text { stock (based on } \\
\text { utilized conver- } \\
\text { sion factors) [tons } \\
\text { year }^{-1} \text { ] }\end{array}$ & $\begin{array}{l}\text { Proportion of } \\
\text { required feedstocks } \\
\text { to collectable bio- } \\
\text { mass [\%] }\end{array}$ \\
\hline P. 1 & Nakhon Sawan & Central & 84.0 & Molasses & $\begin{array}{l}\text { Sugarcane resi- } \\
\text { dues }\end{array}$ & 207,864 & 13 \\
\hline P. 2 & Saraburi & Central & 98.6 & Molasses & $\begin{array}{l}\text { Sugarcane resi- } \\
\text { dues }\end{array}$ & 244,014 & 82 \\
\hline P. 3 & Tak & Central & 84.0 & Molasses & Cassava residues & 207,864 & 68 \\
\hline P. 4 & Kanchanaburi & Central & 73.0 & Molasses & $\begin{array}{l}\text { Sugarcane resi- } \\
\text { dues }\end{array}$ & 180,751 & 12 \\
\hline P. 5 & Kanchanaburi & Central & 109.5 & Molasses & $\begin{array}{l}\text { Sugarcane resi- } \\
\text { dues }\end{array}$ & 271,126 & 18 \\
\hline P. 6 & Suphan Buri & Central & 73.0 & Molasses & $\begin{array}{l}\text { Sugarcane resi- } \\
\text { dues }\end{array}$ & 180,751 & 14 \\
\hline P. 7 & Suphan Buri & Central & 127.8 & Hybrid $^{\mathrm{a}}$ & $\begin{array}{l}\text { Sugarcane resi- } \\
\text { dues }\end{array}$ & 316,314 & 25 \\
\hline P. 8 & Nakhon Pathom & Central & 73.0 & Hybrid & $\begin{array}{l}\text { Sugarcane resi- } \\
\text { dues }\end{array}$ & 180,751 & 101 \\
\hline P. 9 & Ratchaburi & Central & 54.8 & Hybrid & $\begin{array}{l}\text { Sugarcane resi- } \\
\text { dues }\end{array}$ & 135,563 & 35 \\
\hline P. 10 & $\begin{array}{l}\text { Phra Nakhon Si } \\
\text { Ayutthaya }\end{array}$ & Central & 9.1 & Cassava & Rice residues & 24,149 & 9 \\
\hline P. 11 & Lopburi & Central & 73.0 & Cassava & $\begin{array}{l}\text { Sugarcane resi- } \\
\text { dues }\end{array}$ & 180,751 & 13 \\
\hline P. 12 & Khon kaen & Northeastern & 54.8 & Molasses & $\begin{array}{l}\text { Sugarcane resi- } \\
\text { dues }\end{array}$ & 135,563 & 10 \\
\hline P. 13 & $\begin{array}{l}\text { Nakhon Ratch- } \\
\text { asima }\end{array}$ & Northeastern & 73.0 & Molasses & Cassava residues & 57,956 & 5 \\
\hline P. 14 & Kalasin & Northeastern & 84.0 & Molasses & $\begin{array}{l}\text { Sugarcane resi- } \\
\text { dues }\end{array}$ & 207,864 & 24 \\
\hline P. 15 & Kalasin & Northeastern & 116.8 & Molasses & $\begin{array}{l}\text { Sugarcane resi- } \\
\text { dues }\end{array}$ & 289,201 & 33 \\
\hline P. 16 & Chaiyaphum & Northeastern & 182.5 & Molasses & $\begin{array}{l}\text { Sugarcane resi- } \\
\text { dues }\end{array}$ & 451,877 & 36 \\
\hline P. 17 & Sa Kaeo & Northeastern & 54.8 & Hybrid & $\begin{array}{l}\text { Sugarcane resi- } \\
\text { dues }\end{array}$ & 135,563 & 16 \\
\hline P. 18 & Chacherngsao & Northeastern & 73.0 & Hybrid & Cassava residues & 43,467 & 38 \\
\hline P. 19 & Sa Kaeo & Northeastern & 109.5 & Cassava & $\begin{array}{l}\text { Sugarcane resi- } \\
\text { dues }\end{array}$ & 271,126 & 32 \\
\hline P. 20 & Ubonratchatani & Northeastern & 146.0 & Cassava & Cassava residues & 115,913 & 34 \\
\hline P. 21 & Khon kaen & Northeastern & 29.2 & Cassava & $\begin{array}{l}\text { Sugarcane resi- } \\
\text { dues }\end{array}$ & 72,300 & 5 \\
\hline P. 22 & Chonburi & Northeastern & 54.8 & Cassava & Cassava residues & 43,467 & 34 \\
\hline P. 23 & Prachinburi & Northeastern & 21.9 & Cassava & Cassava residues & 17,387 & 20 \\
\hline P. 24 & Prachinburi & Northeastern & 182.5 & Cassava & Cassava residues & 144,891 & 166 \\
\hline P. 25 & $\begin{array}{l}\text { Nakhon Ratch- } \\
\text { asima }\end{array}$ & Northeastern & 124.1 & Cassava & Cassava residues & 98,526 & 9 \\
\hline P. 26 & Chacherngsao & Northeastern & 54.8 & Cassava & Cassava residues & 43,467 & 28 \\
\hline
\end{tabular}

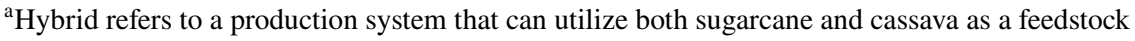


the feed-in materials can be projected from the current status quo. For example, it was estimated that the current feedstocks of plant no. 10, located in Phra Nakhon Si Ayutthaya, could be substituted with rice residues. Assuming that rice residues fed the production plant, it was calculated that 24,149 tons of the feedstock would be needed per year. When looking at the proportion of the required feedstock, this accounted for only $9 \%$ of collectable rice residues in the same provincial area. This result highlighted the immense quantity of available residues.

A similar result was found for plant no. 13, located in Nakhon Ratchasima. The results showed a high potential of available cassava residues. Considering the required alternative feedstocks, 57,956 tons of cassava residues would be needed per year for this production plant, which comprised only $5 \%$ of the collectable biomass in Nakhon Ratchasima. This was primarily based on the high ethanol conversion factors for cassava residues along with a confirmed high availability.

The small proportion of required feedstock in relation to the collectable biomass demonstrates that many ethanol factories have a high potential of utilizing agricultural residues, which are widely available.

\section{Sensitivity Analysis for Uncertainty of Biomass Composition Parameters}

The ethanol production, as estimated in this study, may vary due to a change in the quantity of feedstocks and ethanol conversion factors $\left(E_{\text {conversion }}\right)$. The factors are constructed from the following parameters: residue-to-crop ratio (RSC), moisture content $(M)$, ethanol yield from cellulose $\left(E_{\text {Cellulose }}\right)$ and ethanol yield from hemicellulose $\left(E_{\text {Hemicellulose }}\right)$. These parameters are considered to be affected by uncertainties about biomass properties or technological improvements in the future. The input parameters, which represented mean values in this study, were collected from different literature sources under a variety of experimental conditions, as described in Tables 1-3. To account for uncertainties in the variables, the ranges of obtainable bioethanol were projected by differentiating between individual input parameters. Then, the results of the ethanol estimations were compared with a theoretically calculated base case in order to identify sensitive parameters to influences of parameter variations.

Similar studies with sensitivity analyses have been conducted to explore the effects of changing parameters [103, $118,173]$. For the current analysis, ethanol production was investigated using the Eqs. (1-7) by adjusting values from four parameters: $R S C, M, E_{\text {Cellulose }}$, and $E_{\text {Hemicellulose }}$. The intervals and boundaries of parameter variations used in the sensitivity analysis were acquired from the actual dataset ranges, as calculated in the study, and corresponded to experimental results from literature studies.
For data ranges of parameter variations, the sensitivity analyses were performed in the ranges of the differentiated values and mean values as collected in Table 2. In the case of RSC and moisture content, the established scope of parameter variations was based on the actual ranges of collected data. For example, based on the reviewed literature, the moisture content of cassava pulp and palm leaves in the baseline scenario was $70 \%-80 \%$, which is considered to be relatively high. The compared scenarios of moisture content that exceed $125 \%$ of the base case would provide negative values for ethanol production.

Based on the principle that cellulose content $(C)$ and hemicellulose content $(H)$ are key factors in ethanol conversion, proportions and convertibility of such components were used as references for the ranges of the variables. It was found that the data on cellulose and hemicellulose content collected in this study showed the values deviated between $\pm 10 \%$ and $\pm 100 \%$. Nevertheless, it is also necessary to consider the effects of different pretreatment and hydrolysis processes, along with the ranges of compositions. The conversion of glucose through cellulose hydrolysis was estimated to be in the range of $50 \%-70 \%$ from dilute acid, which may increase to $90 \%$ as a result of a higher acid concentration or the enzymatic hydrolysis process. Meanwhile, the conversion of xylose through hemicellulose hydrolysis can vary between $45 \%$ and $98 \%$ of the theoretical conversion depending on the pretreatment method [174]. As the summarized values from a study by Kumar et al. indicate, hydrolysis and fermentation of cellulose to ethanol were diverse, equaling $70 \%-95 \%$ of the theoretical values, whereas the conversion of xylans to ethanol ranged between $57 \%$ and

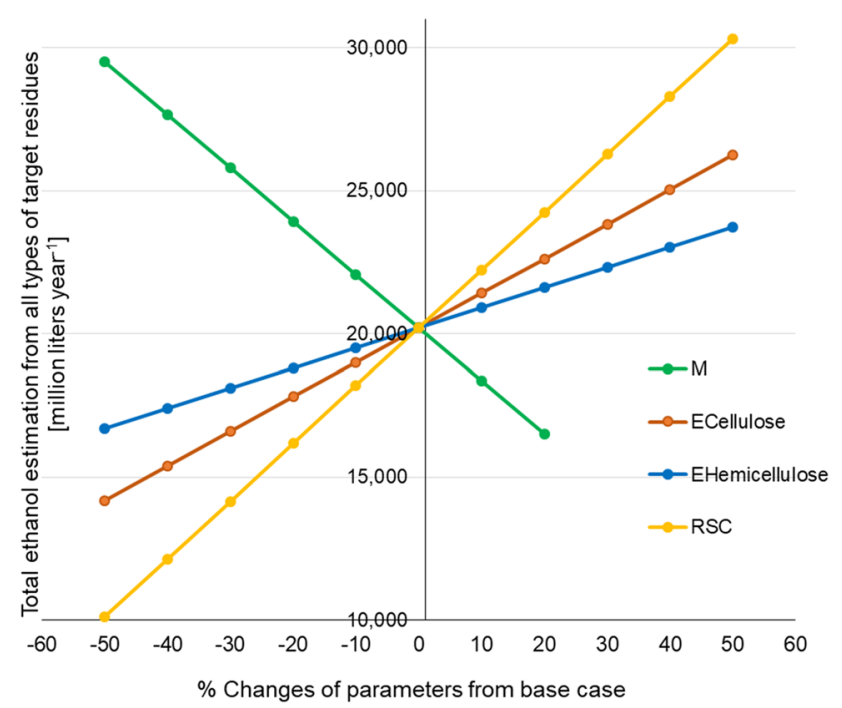

Fig. 8 Sensitivity analysis illustrating the influence on bioethanol production of changing variations of the four parameters: residue-tocrop ratio $(R S C)$, moisture content $(M)$, ethanol yield from cellulose $\left(E_{\text {Cellulose }}\right)$, and ethanol yield from hemicellulose $\left(E_{\text {Hemicellulose }}\right)$ 
90\% depending on the technology and process conditions [175]. Hence, apart from the change in the moisture variable, for the sensitivity analysis performed in the current study, the parameters varied from the base case within the $\pm 50 \%$ for the upper and lower boundaries.

The results in Fig. 8 illustrate the effect from varying values of each parameter. The results of the diverse parameter values revealed that RSC was the most sensitive parameter. When residue conversions were $50 \%$ higher, ethanol estimation was expected to increase to 30,320.2 million liters, an increase of $50 \%$ over the base case. Moisture content is the next sensitive parameter whereby $50 \%$ less moisture contributed to $29,517.9$ million liters, a $46 \%$ higher obtainable volume of ethanol over the base case. Meanwhile, a 50\% increase in the variable values of $E_{\text {Cellulose }}$, and $E_{\text {Hemicellulose }}$ affected ethanol estimates, increasing $29.89 \%$, and $17.4 \%$ respectively.

The $R S C$ and $M$ directly influence the quantity of the input materials, emphasizing the significance of the amounts and types of feed-in materials for ethanol production. As the analysis shows, every $10 \%$ increase in $R S C$ results in changes in the volume of ethanol production of $10 \%-50 \%$. For every $10 \%$ of $M$ reduction, it is possible to expect increasing volumes of ethanol production ranging from $9.2 \%$ to $46.0 \%$. Ethanol yield is basically a conversion of dry weight biomass; therefore, lower proportions of moisture result in larger obtainable volumes of bioethanol per unit of biomass. This also impacts logistic feasibility in terms of the deterioration of feedstock quality and transportation [104]. The moisture in the biomass does not directly inhibit the pretreatment potential of lignocellulosic components, however it could influence the pretreatment efficiency as it requires a longer residence time for a pretreatment reaction [176, 177].

According to the dataset from literature, biochemical compositions in the individual types of biomass are comparatively constant variables. In other words, enhancement of ethanol derivation in the future has to rely on technical improvements to increase hemicellulose and cellulose conversion. The results confirmed the selection of input lignocellulosic biomass, implying the necessity of ethanol conversion from cellulosic compositions in order to acquire higher efficiency in ethanol production. Corresponding to the system design for decentralization, the outcomes from the sensitivity analysis can be referred to as criteria for selecting preferable feedstocks in mixed input materials, focusing on the high RSC values, high-cellulosic content, and lower moisture content of agricultural residues. In addition to the implication for selecting adequate input materials, the compositions of the raw materials, as examined in the scenario study, can help design optimal pretreatment processes associated with effective methods for fractionating cellulose and hemicellulose in biorefineries [178], as well as the necessity of dehydrating high-moisture residues, for instance cassava residues, to achieve the techno-economic feasibility [104].

\section{Conclusions}

The study assesses the potential of the top four mostproduced agricultural residues in Thailand with regard to quantity and primary quality for bioethanol conversion. The total availability of agricultural residues indicates that Thailand has surplus resources of lignocellulosic biomass, which can be sufficiently utilized in bioethanol production to meet the business-as-usual production rate and for the rising consumption in the future. In addition to the strong argument of abundant residue availability, the prospective volume of bioethanol production from the selected biomass was examined. The bioethanol potentials were estimated based on calculations that incorporated the residue-to-crop ratio, moisture content, and chemical compositions of each kind of biomass included in the study, as reported in laboratory studies from the literature. The study obtained pragmatic values which assisted in acquiring rational results for realistic bioethanol projections. It is reasonable to apply the conversion factors derived in the study to estimate bioethanol production from the same types of lignocellulosic biomass.

The goal of the study to propose sustainable system transitioning from centralized to decentralized bioethanol production was accomplished by confirming geographic information on crop distribution and spatial ethanol potential. The spatial data of biomass distribution showed the distinct characteristics of biomass distribution in the country. The central and northeastern regions of Thailand attained the highest potential for material generation as a result of the residual biomass from sugarcane. On the other hand, rice cultivation took up the most farm area in the country. When residue densities were compared, production per area for palm residues is higher in some areas than biomass derived from sugarcane. The availability of palm residues, concentrated in the southern part of Thailand, hinted at the south being a feasible location to broaden resource utilization. The findings of such a regionalized assessment of biomass distribution give rise to a future scenario of decentralizing the facilities of second-generation bioethanol.

Due to the variation of biomass availability and bioethanol conversion, the results implied the possibility of designing a mixture of alternative biomass from different sources, which may lead to a stabilization through combining input materials. For example, although the bioethanol estimation from cassava-derived by-products was not as high as for the other feedstocks, it showed promising results due to the high range of conversion factors. By verifying feedstock substitution, existing production plants can use alternative feedstocks that are locally available. Even though the assessment of industrial feasibility requires an in-depth analysis of technical and economic aspects, this study aims to emphasize the 
examination of the capabilities of up-stream resources for potential industrialized implementation in second-generation bioethanol production.

The results obtained in this study must be understood as being solely a potential analysis. Since all of the conversion factors evaluated in this study were calculated on a theoretical basis, realistic implementation is accompanied by several constraints in scaling up to an industrial level. These include biomass collection facilities, the stability of biomass supply, and seasonal factors. Although commercialization needs to overcome several limitations, this study was able to confirm the total generation of crop residues per year in Thailand and found that various resources are waiting to be made use of.

Although the preliminary assessment in this study did not account for factors from proportions of other applications, in terms of its main objective to verify the maximum amount of generated biomass, its assessment of biomass availability and bioethanol potential in conjunction with the geographic information allowed the study to propose feedstocks and highlight the promising regions and provinces for production plants. The results from the study show the good possibility of decentralizing the second-generation production plants and enhancing the value added for agricultural residues. An examination of upstream levels confirmed the potential of residual resources as the prerequisite step that affects the adequate selection of feedstock types for production in support of decentralized facilities.

Supplementary Information The online version contains supplementary material available at https://doi.org/10.1007/s12649-021-01424-y.

Acknowledgements The authors acknowledge the Ministry of Energy Thailand for the doctoral scholarship of Jusakulvijit P. The authors also thank their colleague from UFZ, David Manske, for his advice on GIS maps creation.

Author Contributions $\mathrm{PJ}$ and $\mathrm{AB}$ conceived the presented ideas. PJ conducted the data curation and general analysis. AB and DT supervised and edited the production of the manuscript.

Funding Open Access funding enabled and organized by Projekt DEAL. The project, as part of doctoral research, was financed by the Energy Conservation Promotion Fund (ENCON Fund) of the Royal Thai Government, Ministry of Energy (Thailand).

\section{Declarations}

Conflict of interest The authors declare no conflict of interest.

Open Access This article is licensed under a Creative Commons Attribution 4.0 International License, which permits use, sharing, adaptation, distribution and reproduction in any medium or format, as long as you give appropriate credit to the original author(s) and the source, provide a link to the Creative Commons licence, and indicate if changes were made. The images or other third party material in this article are included in the article's Creative Commons licence, unless indicated otherwise in a credit line to the material. If material is not included in the article's Creative Commons licence and your intended use is not permitted by statutory regulation or exceeds the permitted use, you will need to obtain permission directly from the copyright holder. To view a copy of this licence, visit http://creativecommons.org/licenses/by/4.0/.

\section{References}

1. International Renewable Energy Agency (IRENA), Energy Outlook https://www.irena.org/-/media/Files/IRENA/Agency/Publi cation/2017/Nov/IRENA_Outlook_Thailand_2017.pdf. (2017). Accessed 13 June 2019

2. Department of Energy Business, Ministry of Energy. http://www. doeb.go.th/2017/EN_index.html?ln=en\#/. Accessed 4 Feb 2020

3. Department of Land Transport S Department of Land Transport, statistics. https://web.dlt.go.th/statistics/. Accessed 4 Feb 2020

4. Chaiyapa, W., Esteban, M., Kameyama, Y.: Why go green ? Discourse analysis of motivations for Thailand's oil and gas companies to invest in renewable energy. Energy Policy 120, 448-459 (2018)

5. United Nations Framework Convention on Climate Change UNFCC.: Thailand's Third National Communication,. https:// www4.unfccc.int/sites/SubmissionsStaging/NationalReports/ Documents/52047631_Thailand-NC3-1-Thailand.TNC.pdf. Accessed 4 Nov 2019

6. Information Technology and Communication Center, Ministry of Commerce. http://tradereport.moc.go.th/TradeThai.aspx. Accessed 17 Oct 2019

7. Energy Policy and Planning Office, Ministry of Energy Thailand (2015) Alternative Energy Development Plan : AEDP2015. http://www.eppo.go.th/index.php/en/policy-andplan/en-tieb/tieb-aedp. Accessed 5 Nov 2019

8. Kumar, S., Salam, P.A., Shrestha, P., Ackom, E.K.: An assessment of thailand's biofuel development. Sustain 5, 1577-1597 (2013)

9. Thrän, D., Arendt, O., Banse, M., Braun, J., Fritsche, U., Gärtner, S., Hennenberg, K.J., Hünneke, K., Millinger, M., Ponitka, J., Rettenmaier, N., Schaldach, R., Schüngel, J., Wern, B., Wolf, V.: Strategy elements for a sustainable bioenergy policy based on scenarios and systems modeling: germany as example. Chem. Eng. Technol. 40, 211-226 (2017)

10. Silalertruksa, T., Gheewala, S.H.: Environmental sustainability assessment of bio-ethanol production in Thailand. Energy 34, 1933-1946 (2009)

11. Papong, S., Rewlay-ngoen, C., Itsubo, N., Malakul, P.: Environmental life cycle assessment and social impacts of bioethanol production in Thailand. J. Clean. Prod. 157, 254-266 (2017)

12. Sornpoon, W., Bonnet, S., Kasemsap, P., Prasertsak, P., Garivait, S.: Estimation of emissions from sugarcane field burning in thailand using bottom-up country-specific activity data. Atmosphere 5, 669-685 (2014)

13. Alkimim, A., Clarke, K.C.: Land use change and the carbon debt for sugarcane ethanol production in Brazil. Land Use Policy 72, 65-73 (2018)

14. Tyner, W.E., Taheripour, F.: Land-Use Changes and $\mathrm{CO}_{2}$ Emissions Due to US Corn Ethanol Production. Encycl. Biodivers. Second. Ed. (2013)

15. Nguyen, T.H., Williams, S., Paustian, K.: Impact of ecosystem carbon stock change on greenhouse gas emissions and carbon payback periods of cassava-based ethanol in Vietnam. Biomass Bioenergy. 100, 126-137 (2017)

16. Popp, J., Lakner, Z., Harangi-Rákos, M., Fári, M.: The effect of bioenergy expansion: Food, energy, and environment. Renew. Sustain. Energy. Rev. 32, 559-578 (2014) 
17. Kumar, J., Reetu, S., Tewari, L.: Lignocellulosic agriculture wastes as biomass feedstocks for second-generation bioethanol production: concepts and recent developments Jitendra. 3 Biotech. 5, 337-353 (2015)

18. Singhania, R.R., Agarwal, R.A., Kuamr, R.P. Sukumaran, R.K..: Waste to Wealth Overview. Springer, Energy, Environment, and Sustainability (2018)

19. Sarkar, N., Ghosh, S.K., Bannerjee, S., Aikat, K.: Bioethanol production from agricultural wastes: An overview. Renew Energy 37, 19-27 (2012)

20. Barz, M., Delivand, M.K.: Agricultural Residues as Promising Biofuels for Biomass Power Generation in Thailand. J. Sustain. Energy Environ. Spec. Issue 21-27(2016)

21. Suramaythangkoor, T., Gheewala, S.H.: Potential alternatives of heat and power technology application using rice straw in Thailand. Appl Energy 87, 128-133 (2010)

22. Limayem, A., Ricke, S.C.: Lignocellulosic biomass for bioethanol production: current perspectives, potential issues and future prospects. Prog. Energy Combust. Sci. 38, 449-467 (2012)

23. Pooja, N.S., Sajeev, M.S., Jeeva, M.L., Padmaja, G.: Bioethanol production from microwave-assisted acid or alkali-pretreated agricultural residues of cassava using separate hydrolysis and fermentation (SHF). 3 Biotech 8, 1-12 (2018)

24. Aditiya, H.B., Chong, W.T., Mahlia, T.M., Sebayang, A.H., Berawi, M.A., Nur, H.: Second generation bioethanol potential from selected Malaysia's biodiversity biomasses: A review. Waste Manag. 47, 46-61 (2016)

25. Anwar, Z., Gulfraz, M., Irshad, M.: Agro-industrial lignocellulosic biomass a key to unlock the future bio-energy: A brief review. J. Radiat. Res. Appl. Sci. 7, 163-173 (2014)

26. Kumari, D., Singh, R.: Pretreatment of lignocellulosic wastes for biofuel production: A critical review. Renew Sustain. Energy Rev. 90, 877-891 (2018)

27. Pippo, W.A., Luengo, C.A., Alberteris, L.A.M., Garzone, P., Cornacchia, G.: Energy recovery from sugarcane-trash in the light of 2nd generation biofuel. Part 2: Socio-economic aspects and techno-economic analysis. Waste Biomass Valor. 2, 257-266 (2011)

28. de Vries, S.C., van de Ven, G.W.J., van Ittersum, M.K.: First or second generation biofuel crops in Brandenburg, Germany ? A model-based comparison of their production-ecological sustainability. Eur. J. Agron. 52, 166-179 (2014)

29. Gregg, J.S., Smith, S.J.: Global and regional potential for bioenergy from agricultural and forestry residue biomass. Mitig. Adapt. Strateg. Glob. Chang. 15, 241-262 (2010)

30. Yusianto, R., Marimin, S., Hardjomidjojo, H.: Green Logistics Approach in Bioethanol Conversion from Potato Starch in Central Java. IOP Conf. Ser. Mater. Sci. Eng. 598, 012100 (2019)

31. Ramamurthi, P.V., Fernandes, C.M., Nielsen, P.S., Nunes, C.P.: Logistics cost analysis of rice residues for second generation bioenergy production in Ghana. Bioresour. Technol. 173, 429-438 (2014)

32. Hildebrandt, J., Bezama, A., Thrän, D.: Insights from the sustainability monitoring tool SUMINISTRO applied to a case study system of prospective wood-based industry networks in central Germany. Sustain. 12, 3896 (2020)

33. Bruins, M.E., Sanders, J.P.M.: Small-scale processing of biomass for biorefinery. Biofuels Bioprod. Biorefin. 6, 135-145 (2012)

34. Fytili, D., Zabaniotou, A.: circular economy synergistic opportunities of decentralized thermochemical systems for bioenergy and biochar production fueled with agro-industrial wastes with environmental sustainability and social acceptance: a review. Curr. Sustain. Energy Rep. 5, 150-155 (2018)
35. Kim, S., Dale, B.E.: Comparing alternative cellulosic biomass biorefining systems: Centralized versus distributed processing systems. Biomass Bioenergy 74, 135-147 (2015)

36. Delivand, M.K., Barz, M., Gheewala, S.H.: Logistics cost analysis of rice straw for biomass power generation in Thailand. Energy 36, 1435-1441 (2011)

37. Zhu, X., Yao, Q.: Logistics system design for biomass-to-bioenergy industry with multiple types of feedstocks. Bioresour. Technol. 102, 10936-10945 (2011)

38. O'Keeffe, S., Thrän, D.: Energy crops in regional biogas systems: An integrative spatial LCA to assess the influence of crop mix and location on cultivation GHG emissions. Sustain. 12, 237 (2020)

39. Jarosch, L., Zeug, W., Bezama, A., Finkbeiner, M., Thrän, D.: A regional socio-economic life cycle assessment of a bioeconomy value chain. Sustain. 12, 1-15 (2020)

40. Goh, C.S., Aikawa, T., Ahl, A., et al.: Rethinking sustainable bioenergy development in Japan: decentralised system supported by local forestry biomass. Sustain Sci. (2019)

41. Quinteiro, P., Greco, F., da Cruz Tarelho, L.A., Righi, S., Arroja, L., Dias, A.C.: A comparative life cycle assessment of centralised and decentralised wood pellets production for residential heating. Sci. Total Environ. 730 (2020)

42. Mangoyana, R.B., Smith, T.F.: Decentralised bioenergy systems: A review of opportunities and threats. Energy Policy 39, 12861295 (2011)

43. Hildebrandt, J., O'Keeffe, S., Bezama, A., Thrän, D.: Revealing the environmental advantages of industrial symbiosis in woodbased bioeconomy networks: an assessment from a life cycle perspective. J. Ind. Ecol. 23(4), 808-822 (2019)

44. Heo, S., Choi, J.W.: Potential and Environmental Impacts of Liquid Biofuel from Agricultural Residues in Thailand. Sustain. 11, 1502 (2019)

45. Garivait, S., Chaiyo, U., Patumsawad, S., Deakhuntod, J.: Physical and Chemical Properties of Thai Biomass Fuels from Agricultural Residues. In: The $2^{\text {nd }}$ Joint International Conference on "Sustainable Energy and Environment (SEE 2006)", C-048 (2006)

46. Office of Agrricultural Economics, Crops production. http:// www.oae.go.th/view/1/Information/EN-US. Accessed 17 Oct 2019

47. Department of Alternative Energy Development and Efficiency (DEDE) - Agricultural residues in Thailand. http://biomass. dede.go.th/biomass_web/index.html. Accessed 17 Oct 2019

48. Office of the Cane and Sugar Board (OCSB), Sugarcane production. http://www.ocsb.go.th/th/cms/detail.php?ID=142\& SystemModuleKey=production. Accessed 14 July 2019

49. Gadde, B., Menke, C., Wassmann, R.: Rice straw as a renewable energy source in India, Thailand, and the Philippines: Overall potential and limitations for energy contribution and greenhouse gas mitigation. Biomass Bioenerg. 33, 1532-1546 (2009)

50. Thanarak, P.: Supply chain management of agricultural waste for biomass utilization and $\mathrm{CO}_{2}$ emission reduction in the lower northern region of Thailand. Energy Procedia 14, 843-848 (2012)

51. Rabelo, S.C., Costa, A.C. da Rossel, C.E.V.: Industrial Waste Recovery. Sugarcane Agric. Prod. Bioenergy Ethanol. 365-381 (2015)

52. Moreira, J.R.: Sugarcane for energy - recent results and progress in Brazil. Energy Sustain. Dev. 4, 43-54 (2000)

53. Gnansounou, E., Dauriat, A.: Ethanol fuel from biomass : A review. J. Sci. Ind. Res. 64, 809-821 (2005)

54. Papong, S., Yuvaniyama, C., Lohsomboon, P., Malakul, P.: Overview of Biomass Utilization in Thailand, The meeting for LCA 
in ASEAN Biomass Project, International Conference Center EPOCHAL TSUKUBA, Japan. (2004)

55. Gómez, E.O., Torres, R., Souza, G.De., Jackson, G.: Sugarcane trash as feedstock for second generation processes. Sugarcane bioethanol - R\&D Prod Sustain. 637-660.

56. Zhang, Y., Ghaly, A.E., Li, B.: Availability and physical properties of residues from major agricultural crops for energy conversion through thermochemical processes. Am. J. Agric. Biol. Sc. 7, 312-321 (2012)

57. Khatiwada, D., Silveira, S.: Greenhouse gas balances of molasses based ethanol in Nepal. J. Clean Prod. 19, 1471-1485 (2011)

58. Djumaali, D., Soewarno, N., Sumarno, S., Primarini, D., Sumaryono, W.: Cassava pulp as a biofuel feedstock of an enzymatic hydrolysis process, Makara. J. Technol. 15, 183-192 (2011)

59. Chauynarong, N., Bhuiyan, M.M., Kanto, U., Iji, P.A.: Variation in Nutrient Composition of Cassava Pulp and its Effects on in vitro Digestibility. Asian J. Poult. Sci. 9, 203-212 (2015)

60. Kosugi, A., Kondo, A., Ueda, M., Murata, Y., Vaithanomsat, P., Thanapase, W., Arai, T., Mori, Y.: Production of ethanol from cassava pulp via fermentation with a surface-engineered yeast strain displaying glucoamylase. Renew. Energy. 34, 1354-1358 (2009)

61. Sriroth, K., Chollakup, R., Chotineeranat, S., Piyachomkwan, K., Oates, C.G.: Processing of cassava waste for improved biomass utilization. Bioresour Technol 71, 63-69 (2000)

62. Nuwamanya, E., Chiwona-karltun, L., Kawuki, R.S., Baguma, Y.: Bio-Ethanol Production from Non-Food Parts of Cassava (Manihot esculenta Crantz). Ambio 41, 262-270 (2012)

63. Elechi, O.O., Tagbo, N.J., Mary, O.C., Emmanuel, A.O.: Acid Hydrolysis Of Cassava Peel. Int. J. Sci \& Technol. Res. 5, 184 187 (2016)

64. Babayemi, O.J., Ifut, O.J., Inyang, U.A., Isaac, L.J.: Quality and Chemical Composition of Cassava Wastes Ensiled with Albizia saman Pods. Agric. J. 5, 225-228 (2010)

65. Sovorawet, B., Kongkiattikajorn, J.: Bioproduction of Ethanol in SHF and SSF from Cassava Stalks. KKU Res. J. 17, 565-572 (2012)

66. Veiga, J.P.S., Valle, T.L., Feltran, J.C., Bizzo, W.A.: Characterization and productivity of cassava waste and its use as an energy source. Renew. Energy. 93, 691-699 (2016)

67. Tippayawong, N., Rerkkriangkrai, P., Aggarangsi, P., Pattiya, A.: Biochar production from cassava in a semi-continuous carbonization system. Energy Procedia 141, 109-113 (2017)

68. Pattiya, A.: Thermochemical characterization of agricultural wastes from thai cassava plantations. energy sour. Part A: Recov. Utili. Environ. Eff. 33, 691-701 (2011)

69. Sombatpraiwan, S., Junyusen, T., Treeamnak, T., Junyusen, P.: Optimization of microwave - assisted alkali pretreatment of cassava rhizome for enhanced enzymatic hydrolysis glucose yield. Food Energy Secur. 8, e00174 (2019)

70. Kadam, K.L., Forrest, L.H., Jacobson, W.A.: Rice straw as a lignocellulosic resource: collection, processing, transportation, and environmental aspects. Biomass Bioenergy. 18369-389 (2000)

71. Somerville, C., Youngs, H., Taylor, C., Davis, S.C., Long, S.P.: Feedstocks for Lignocellulosic Biofuels. Science 329, 790-792 (2010)

72. Ahmad, F.B., Zhang, Z., Doherty, W.O.S., O’Hara, I.M.: The outlook of the production of advanced fuels and chemicals from integrated oil palm biomass biorefinery. Renew. Sustain. Energy Rev. 109, 386-411 (2019)

73. Suksong, W., Mamimin, C., Prasertsan, P., Kongjan, P., O-Thong, S., : Effect of inoculum types and microbial community on thermophilic and mesophilic solid-state anaerobic digestion of empty fruit bunches for biogas production. Ind. Crops Prod. 133, 193202 (2019)
74. Rupani, P.F., Singh, R.P., Ibrahim, M.H., Esa, N.: Review of Current Palm Oil Mill Effluent ( POME ) Treatment Methods : Vermicomposting as a Sustainable Practice. World Appl. Sci. J. 10, 1190-1201 (2010)

75. Aziz, M.A., Uemura, Y., Sabil, K.M.: Characterization of oil palm biomass as feed for torrefaction process. National Postgraduate Conference (NPC), IEEE (2011)

76. Abdullah, N., Sulaiman, F.: The Oil Palm Wastes in Malaysia. Biomass Now - Sustainable Growth and Use, Miodrag Darko Matovic, IntechOpen (2013)

77. Adeyemi, O.I., Ademoh, N.A., Boye, T.E.: Development of asbestos - free automotive brake pad using ternary agro-waste fillers. J. Multidiscip. Eng. Sci. Technol. 3, 5307-5323 (2016)

78. Ahmad, R., Hamidin, N.: Characterization of bio-oil from palm kernel shell pyrolysis. J. Mech. Eng. Sci. 7, 1134-1140 (2014)

79. Sulaiman, S.A., Guangul, F.M., Konda, R.E., Atnaw, S.M., Moni, M.N.: Estimation of moisture content of oil palm fronds through correlation with density for the process of gasification. BioResour. 11, 8941-8952 (2016)

80. Unrean, P., Ketsub, N.: Industrial Crops \& Products Integrated lignocellulosic bioprocess for co-production of ethanol and xylitol from sugarcane bagasse. Ind. Crop Prod. 123, 238-246 (2018)

81. Ye, G., Zeng, D., Zhang, S., Fan, M., Zhang, H., Xie, J.: Ethanol production from mixtures of sugarcane bagasse and Dioscorea composita extracted residue with high solid loading. Bioresour. Technol. 257, 23-29 (2018)

82. Pereira, S.C., Maehara, L., Machado, C.M.M., Farinas, C.S.: 2G ethanol from the whole sugarcane lignocellulosic biomass. Biotechnol. Biofuels. 8, 1-16 (2015)

83. Menandro, L.M.S., Cantarella, H., Franco, H.C.J., Kölln, O.T., Pimenta, M.T.B., Sanches, G.M., Rabelo, S.C., Carvalho, J.L.N.: Comprehensive assessment of sugarcane straw : implications for biomass and bioenergy production. Biofuels Bioprod. Bioref. 11, 488-504 (2017)

84. Sindhu, R., Kuttiraja, M., Binod, P., Sukumaran, R.K., Pandey, A.: Physicochemical characterization of alkali pretreated sugarcane tops and optimization of enzymatic saccharification using response surface methodology. Renew Energy 62, 362-368 (2014)

85. Patil, R.A., Bavda, K.: Dry Sugarcane Leaves : Renewable Biomass resources for Making Briquettes. Int. J. Eng. Res. Technol. 10, 232-235 (2017)

86. Thongchul, N., Navankasattusas, S., Yang, S.T.: Production of lactic acid and ethanol by Rhizopus oryzae integrated with cassava pulp hydrolysis. Bioprocess Biosyst. Eng. 33, 407-416 (2010)

87. Aderemi, F.A., Nworgu, F.C.: Nutritional Status of Cassava Peels and Root Sieviate Biodegraded With Aspergillus niger. American-Eurasian J. Agric. \& Environ. Sci. 2, 308-311 (2007)

88. Rafein, M., Hirata, S., Ali, M.: Bioresource Technology Hydrothermal pretreatment enhanced enzymatic hydrolysis and glucose production from oil palm biomass. Bioresour. Technol. 176, 142-148 (2015)

89. Ahmad, F.B., Zhang, Z., Doherty, W.O.S., Hara, I.M.O., Crops, T.: Evaluation of oil production from oil palm empty fruit bunch by oleaginous micro-organisms. Biofuels Bioprod. Bioref. 10, 378-392 (2016)

90. Huzairi, M., Zainudin, M., Aini, N., Rahman, A., Abd-aziz, S.: Utilization of Glucose Recovered by Phase Separation System from Acid-hydrolysed Oil Palm Empty Fruit Bunch for Bioethanol Production. Pertanika J. Trop. Agric. Sci. 35, 117-126 (2012)

91. Ariffin, H., Hassan, M.A., Shah, U.K., Abdullah, N., Ghazali, F.M., Shirai, Y.: Production of Bacterial Endoglucanase from Pretreated Oil Palm Empty Fruit Bunch by Bacillus pumilus EB3. J. Biosci. Bioeng. 106, 231-236 (2008) 
92. Rahman, S.H.A., Choudhury, J.P., Ahmad, A.L.: Production of xylose from oil palm empty fruit bunch fiber using sulfuric acid. Biochem. Eng. J. 30, 97-103 (2006)

93. Abnisa, F., Arami-niya, A., Daud, W.M.A.W., Sahu, J.N.: Characterization of Bio-oil and Bio-char from Pyrolysis of Palm Oil Wastes. BioEnergy. Res. 6, 830-840 (2013)

94. Asadieraghi, M., Mohd, W., Wan, A.: Characterization of lignocellulosic biomass thermal degradation and physiochemical structure : Effects of demineralization by diverse acid solutions. Energy Convers. Manag. 82, 71-82 (2014)

95. Saka, S., Manusamy, M.V., Shibata, M., Tono, Y., Miyafuji, H.: Chemical constituents of the different anatomical parts of the oil palm (elaeis guineensis) for their sustainable utilization. seminar proceedings - natural resour. Energy Environ. JSPS-VCC. 19-34 (2008)

96. Abnisa, F., Arami-niya, A., Daud, W.M.A.W., Sahu, J.N., Noor, I.M.: Utilization of oil palm tree residues to produce bio-oil and bio-char via pyrolysis. Energy Convers. Manag. 76, 1073-1082 (2013)

97. Mood, S.H., Golfeshan, A.H., Tabatabaei, M., Jouzani, G.S., Najafi, G.H., Gholami, M., Ardjmand, M.: Lignocellulosic biomass to bioethanol, a comprehensive review with a focus on pretreatment. Renew. Sustain. Energy Rev. 27, 77-93 (2013)

98. Braune, M., Gröngröft, A., Oehmichen, K., Zech, K.: Die Biokraftstoffproduktion in Deutschland - Stand der Technik und Optimierungsansätze. DBFZ-Report, 22. Leipzig: DBFZ. 251 S. ISBN: 978-3-9817707-8-0 (2016) https://www.dbfz. de/pressemediathek/publikationsreihen-des-dbfz/dbfz-reports/ dbfz-report-nr-22/.

99. Jahnavi, G., Prashanthi, G.S., Sravanthi, K., Rao, L.V.: Status of availability of lignocellulosic feed stocks in India: Biotechnological strategies involved in the production of Bioethanol. Renew. Sustain. Energy Rev. 73, 798-820 (2017)

100. Demirbas, A.: Bioethanol from Cellulosic Materials: A Renewable Motor Fuel from Biomass. Energy Sour. 27, 327-337 (2005)

101. Gulati, M., Kohlmann, K., Ladisch, M.R., Hespell, R., Bothast, R.J.: Assessment of ethanol production options for corn products. Bioresour Technol. 58, 253-264 (1996)

102. Breuninger., W.F., Piyachomkwan, K., Sriroth, K.: Tapioca/ Cassava Starch: Production and Use. Starch Chem Technol Third Edit. ISBN: 978-0-12-746275-2 (2009)

103. Nguyen, T.L.T., Gheewala, S.H., Garivait, S.: Full chain energy analysis of fuel ethanol from cassava in Thailand. Environ. Sci. Technol. 41, 4135-4142 (2007)

104. Julian, A.Q., Carlos, A.C., Erika, F., Jonathan, M., Juan, C.H.: Techno-economic analysis of fuel ethanol production from cassava in Africa: The case of Tanzania. African J. Biotechnol. 14, 3082-3092 (2015)

105. Department of Alternative Energy Development and Efficiency. Ministry of Energy. Ethanol production plants by materials (2019) http://www.dede.go.th/ewt_dl_link.php?nid=329. Accessed 04 Jan 2020

106. Burnes, E., Wichelns, D., Hagen, J.W.: Economic and policy implications of public support for ethanol production in California's San Joaquin Valley. Energy Policy 33, 1155-1167 (2005)

107. Department of Alternative Energy Development and Efficiency Renewable Energy Proportions in Thailand. https://www.dede. go.th/ewt_news.php?nid=48247. Accessed 17 Oct 2019

108. Department of Energy Business. Ministry of Energy. E-Law System. http://elaw.doeb.go.th/home_en.php. Accessed 19 June 2019

109. Food and Agriculture Organization (FAO). FAOSTAT. http:// www.fao.org/faostat/en/?\#home. Accessed 17 Oct 2019

110. Statista. Sugarcane production volume Thailand 2016-2018. https://www.statista.com/statistics/1041070/thailand-sugarcaneproduction-volume/. Accessed 17 June 2019
111. Piyachomkwan, K., Tanticharoen, M.: Cassava Industry in Thailand Prospects. J. R. Inst. Thail. 3:160-170 (2011) http://www. royin.go.th/royin2014/upload/246/FileUpload/2532_3748.pdf

112. Nguyen, T.L.T., Gheewala, S.H., Garivait, S.: Energy balance and GHG-abatement cost of cassava utilization for fuel ethanol in Thailand. Energy Policy 35, 4585-4596 (2007)

113. Sriroth, K., Wanlapatit, S., Piyachomkwan, K., Cassava Bioethanol. IntechOpen. (2012) https://www.intechopen.com/books/ bioethanol/-cassava-bioethanol

114. Arthey, T., Srisompun, O., Zimmer, Y.: Cassava Production and Processing in Thailand Report to FAO Agribenchmark (2018) http://www.agribenchmark.org/fileadmin/Dateiablage/B-CashCrop/Reports/CassavaReportFinal-181030.pdf. Accessed 5 Nov 2019

115. Phengkhouane, M., Bourgois, E.: White Paper: Thai Sugarcane Sector \& Sustainability. Fairagora. (2017) https://www.bonsucro. $\mathrm{com} /$ white-paper-thai-sugarcane-industry-sustainability-relea sed/. Accessed 19 June 2019

116. Traivivatana, S., Wangjiraniran, W., Junlakarn, S., Wansophark, N.: Impact of transportation restructuring on Thailand energy outlook. Energy Procedia 138, 393-398 (2017)

117. Limanond, T., Jomnonkwao, S., Srikaew, A.: Projection of future transport energy demand of Thailand. Energy Policy 39, 2754 2763 (2011)

118. Silalertruksa, T., Gheewala, S.H., Sagisaka, M.: Impacts of Thai bio-ethanol policy target on land use and greenhouse gas emissions. Appl. Energy 86, S170-S177 (2009)

119. Adarme, O.F.H., Baêta, B.E.L., Filho, J.B.G., Gurgel, L.V.A., de Aquino, S.F.: Use of anaerobic co-digestion as an alternative to add value to sugarcane biorefinery wastes. Bioresour. Technol. 287, 121443 (2019)

120. Wakamura, Y.: Utilization of bagasse energy in Thailand. Mitigat. Adapt. Strategies. Glob. Chage. 8, 253-260 (2003)

121. Robertson, G.: State-of-the-art biobased food packaging materials. Environ. Compat. Food Package 3-28 (2008)

122. Biodegradable Packaging for Environment Co. Ltd., Biodegradable Packaging for Environment. http://www.thaibpe.com/produ cts_all.html. Accessed 26 Sept 2018

123. KTIS More Than Sugar. Products and sevices. http://www.ktisg roup.com/about/business/product. Accessed 23 Oct 2019

124. Kiatkittipong, W., Wongsuchoto, P., Pavasant, P.: Life cycle assessment of bagasse waste management options. Waste Manag. 29, 1628-1633 (2009)

125. Environment Pulp and Paper Co Ltd. http://www.eppcopulp. com/. Accessed 19 Sep 2019

126. Bioplastic - SugarCane. https://sugarcane.org/bioplastic/. Accessed 19 Sept 2019

127. Liguori, R., Faraco, V.: Bioresource technology biological processes for advancing lignocellulosic waste biorefinery by advocating circular economy. Bioresour. Technol. 215, 13-20 (2016)

128. Restrepo-serna, D.L., Martínez-Ruano, J.A., Cardona-Alzate, C.A.: Energy efficiency of biorefinery schemes using sugarcane bagasse as raw material. Energies 11, 3474 (2018)

129. Chandel, A.K., da Silva, S.S., Carvalho, W., Singh, O.V.: Sugarcane bagasse and leaves: foreseeable biomass of biofuel and bio-products. J. Chem. Technol. Biotechnol. 87, 11-20 (2012)

130. Fortes, C., Vitti, A.C., Otto, R., Ferreira, D.A., Coutinho, H., Franco, J., Cesar, P.: Contribution of nitrogen from sugarcane harvest residues and urea for crop nutrition. Sci. Agric. 70, 313$320(2013)$

131. Mitrphol group. https://www.mitrphol.com/page.php?p=1. Accessed 17 Oct 2019

132. Coutinho, H., Franco, J., Teresa, M., Pimenta, B., Luís, J., Carvalho, N., Graziano, P.S.: Assessment of sugarcane trash for agronomic and energy purposes in Brazil. 305-312 (2013) 
133. Carvalho, J.L.N., Otto, R., Franco, H.C.J., Trivelin, P.C.O.: Input of sugarcane post-harvest residues into the soil. Sci. Agric. 70, 336-344 (2013)

134. Ubalua, A.O.: Cassava wastes : treatment options and value addition alternatives. Afr. J. Biotech. 6, 2065-2073 (2007)

135. Panichnumsin, P., Nopharatana, A., Ahring, B.K., Chaiprasert, P.: Enhanced biomethanation in co-digestion of cassava pulp and pig manure using a two-phase anaerobic system. J. Sustain. Energy Environ. 3, 73-79 (2012)

136. Zhang, J., Xu, J.Y., Wang, D.Q., Ren, N.Q.: Anaerobic digestion of cassava pulp with sewage sludge inocula. BioResour. 11, 451-465 (2016)

137. Hermiati, E., Mangunwidjaja, D., Sunarti, T.C., Suparno, O., Prasetya, B.: Potential utilization of cassava pulp for ethanol production in Indonesia. Sci. Res. Essays 7, 100-106 (2012)

138. Mohd-Asharuddin, S., Othman, N., Zin, M.N.S., Tajarudin, H.A.: A chemical and morphological study of cassava peel: a potential waste as coagulant aid. Int. Symp. Civil Environ. Eng. (ISCEE 2016) 103, 1-8 (2017)

139. The Thai Tapioca Development InstituteTapioca Thai. https:// www.tapiocathai.org/English/Mainpage_e.html. Accessed 16 Sept 2019

140. Meesukanun, K., Satirapipathkul, C.: Production of acetonebutanol-ethanol from cassava rhizome hydrolysate by clostridium saccharobutylicum BAA 117. Chem. Eng. Trans. 37, 421-426 (2014)

141. United States Department of Agriculture Foreign Agricultural Service, Grain : World Markets and Trade. https://apps.fas.usda. gov/psdonline/circulars/grain.pdf. (2020). Accessed 5 Nov 2019

142. NL Agency, Ministry of Economic Affairs: Rice straw and Wheat straw Potential feedstocks for the biobased economy. https://libra ry.wur.n1/WebQuery/wurpubs/fulltext/288866 (2013). Accessed 5 Nov 2019

143. Bakar, R.A., Yahya, R., Gan, S.N.: Production of High Purity Amorphous Silica from Rice Husk. Procedia Chem. 19, 189-195 (2016)

144. Zareei, S.A., Ameri, F., Dorostkar, F., Ahmadi, M.: case studies in construction materials rice husk ash as a partial replacement of cement in high strength concrete containing micro silica : evaluating durability and mechanical properties. Case Stud. Constr. Mater. 7, 73-81 (2017)

145. Silalertruksa, T., Gheewala, S.H.: A comparative LCA of rice straw utilization for fuels and fertilizer in Thailand. Bioresour. Technol. 150, 412-419 (2013)

146. International Rice Research Institiute. Rice Knowledge Bank. http://www.knowledgebank.irri.org/. Accessed 9 Nov 2019

147. Nguyen, H.V., Nguyen, C.D., Tran, T.V., Hau, H.D., Nguyen, N.T., Gummert, M.: Energy efficiency, greenhouse gas emissions, and cost of rice straw collection in the mekong river delta of vietnam. Field Crop Res. 198, 16-22 (2016)

148. Foundation for Agricultural and Environmental Conservation (Thailand). http://www.aecth.org/. Accessed 9 Nov 2019

149. Junpen, A., Pansuk, J., Kamnoet, O., Cheewaphongphan, P., Garivait, S.: Emission of air pollutants from rice residue open burning in Thailand. Atmosphere 9, 449 (2018)

150. Supaporn, P., Kobayashi, T., Supawadee, C.: Factors affecting farmers' decisions on utilization of rice straw compost in Northeastern Thailand. J. Agric. Rural Dev. Trop. Subtrop. 114, 21-27 (2013)

151. Naklang, K., Whitbread, A., Lefroy, R., Blair, G., Wonprasaid, S., Konboon, Y., Suriya-Arunroj, D.: The management of rice straw, fertilisers and leaf litters in rice cropping systems in Northeast Thailand: I. Soil carbon dynamics. Plant Soil 209, 21-28 (1999)
152. Kanokkanjana, K., Garivait, S.: Alternative rice straw management practices to reduce field open burning in Thailand. Int. J. Environ. Sci. Dev. 4, 119-123 (2013)

153. Sarnklong, C., Coneja, J.W., Pellikaan, W., Hendriks, W.H.: Utilization of rice straw and different treatments to improve its feed value for ruminants: a review. Asian-Australasian J. Anim. Sci. 23, 680-692 (2010)

154. Binod, P., Sindhu, R., Singhania, R.R., Vikram, S., Devi, L., Nagalakshmi, S., Kurien, N., Sukumaran, R.K., Pandey, A.: Bioethanol production from rice straw : An overview. Bioresour. Technol. 101, 4767-4774 (2010)

155. Nagrale, S.D., Hajare, H., Modak, P.R.: Utilization Of Rice Husk Ash. Int. J. Eng. Res. Appl. 2, 1-5 (2012)

156. Liu, N., Huo, K., McDowell, M.T., Zhao, J., Cui, Y.: Rice husks as a sustainable source of nanostructured silicon for high performance Li-ion battery anodes. Sci. Rep. 3, 1-7 (2013)

157. Petchseechoung, W.: Thailand Industry Outlook 2017-19 - Oil palm industry. Krungsri Research https://www.krungsri.com/ bank/getmedia/ac87c171-db74-442b-ae29-5b69572896ca/IO_ Oil_Palm_2017_EN.aspx. (2017). Accessed 9 Nov 2019

158. Beaudry, G., Macklin, C., Roknich, E., Sears, L., Wiener, M., Gheewala, S.H.: Greenhouse gas assessment of palm oil mill biorefinery in Thailand from a life cycle perspective. Biomass Conv. Bioref. 8, 43-58 (2018)

159. Prasertsan, S., Prasertsan, P.: Biomass residues from palm oil mills in Thailand: An overview on quantity and potential usage. Biomass Bioenergy 11, 387-395 (1996)

160. Iberahim, N.I., Jahim, J.M., Harun, S., Tusirin, M., Nor, M.T., Hassan, O.: Sodium Hydroxide Pretreatment and Enzymatic Hydrolysis of Oil Palm Mesocarp Fiber. Int. J. Chem. Eng. Appl. 4, 101-105 (2013)

161. Bazargan, A., Rough, S.L., McKay, G.: Compaction of palm kernel shell biochars for application as solid fuel. Biomass Bioenergy 70, 489-497 (2014) http://hdl.handle.net/1783.1/64468

162. Lecksiwilai, N., Gheewala, S.H., Sagisaka, M., Yamaguchi, K.: Net Energy Ratio and Life cycle greenhouse gases (GHG) assessment of bio-dimethyl ether (DME) produced from various agricultural residues in Thailand. J. Clean Prod. 134, 523-531 (2016)

163. Bakar, R.A., Darus, S.Z., Kulaseharan, S., Jamaluddin, N.: Effects of ten year application of empty fruit bunches in an oil palm plantation on soil chemical properties. Nutr. Cycl. Agroecosystems 89, 341-349 (2011)

164. Zaharah, A.R., Lim, K.C.: Oil palm empty fruit bunch as a source of nutrients and soil ameliorant in oil palm plantation. Malaysian J. Soil Sci. 4, 51-66 (2000)

165. Chavalparit, O., Rulkens, W.H., Mol, A.P.J., Khaodhair, S.: Options for environmental sustainability of the crude palm oil industry in Thailand through enhancement of industrial ecosystems. Environ. Dev. Sustain. 8, 271-287 (2006)

166. Cheewaphongphan, P., Junpen, A., Kamnoet, O., Garivait, S.: Study on the potential of rice straws as a supplementary fuel in very small power plants in Thailand. Energies 11, 270 (2018)

167. Cheewaphongphan, P., Garivait, S.: Bottom up approach to estimate air pollution of rice residue open burning in Thailand. AsiaPacific J. Atmos. Sci. 49, 139-149 (2013)

168. Majer, S., Stecher, K., Adler, P., Thrän, D., Müller-Langer, F.: Biomass potentials and competition for biomass utilisation. Short study in the context of the scientific supervision, support and guidance of the BMVBS in the sectors Transport and Mobility with a specific focus on fuels and propulsion technologies, as well as energy and climate. https://www.bmvi.de/SharedDocs/ EN/Documents/MKS/mks-short-study-biomass-potentials-andcompetition-for-biomass-utilisation.pdf?_blob=publicationFile. Accessed 31 Jan 2021 
169. Muscat, A., de Olde, E.M., de Boer, I.J.M., Ripoll-Bosch, R.: The battle for biomass: A systematic review of food-feed-fuel competition. Glob. Food Sec. 25 (2020)

170. Joppert, C.L., dos Santos, M.M., Costa, H.K.M., dos Santos, E.M., Moreira Simões, J.R.: Energetic shift of sugarcane bagasse using biogas produced from sugarcane vinasse in Brazilian ethanol plants. Biomass Bioenergy 107, 63-73 (2017)

171. Oke, M.A., Annuar, M.S.M., Simarani, K.: Mixed Feedstock Approach to Lignocellulosic Ethanol Production-Prospects and Limitations. Bioenergy Res. 9, 1189-1203 (2016)

172. Lemire, P.O., Delcroix, B., Audy, J.F., Labelle, F., Mangin, P., Barnabé, S.: GIS method to design and assess the transportation performance of a decentralized biorefinery supply system and comparison with a centralized system: case study in southern Quebec, Canada. Biofuels. Bioprod. Bioref. 13, 552-567 (2019)

173. Macrelli, S., Mogensen, J., Zacchi, G.: Techno-economic evaluation of 2nd generation bioethanol production from sugar cane bagasse and leaves integrated with the sugar-based ethanol process. Biotechnol. Biofuels 5, 22 (2012)

174. Hamelinck, C.N., Van Hooijdonk, G., Faaij, A.P.C.: Ethanol from lignocellulosic biomass: Techno-economic performance in short-, middle- and long-term. Biomass Bioenergy 28, 384-410 (2005)

175. Kumar, D., Murthy, G.S.: Impact of pretreatment and downstream processing technologies on economics and energy in cellulosic ethanol production. Biotechnol. Biofuels 4, 27 (2011)

176. Tucker, M.P., Kim, K.H., Newman, M.M., Nguyen, Q.A.: Effects of temperature and moisture on dilute-acid steam explosion pretreatment of corn stover and cellulase enzyme digestibility. Appl Biochem Biotechnol. 105, 65-177 (2003)

177. Quintero, J.A., Rincón, L.E., Cardona, C.A.: Production of bioethanol from agroindustrial residues as feedstocks. Biofuels 251-285 (2011)

178. Carvalheiro, F., Duarte, L.C., Gírio, F.M.: Hemicellulose biorefineries: A review on biomass pretreatments. J. Sci. Ind. Res. 67, 849-864 (2008)

Publisher's Note Springer Nature remains neutral with regard to jurisdictional claims in published maps and institutional affiliations. 